ON THE

\title{
INFLUENCE OF VARIOUS DIETS UPON THE COMPOSITION OF THE URINE
}

\author{
AND \\ THE GENERAL CONDITION OF PATIENTS SUFFERING \\ FROM CHRONIC BRIGHT'S DISEASE.
}

BY

W. HALE WHITE, M.D.,

PHYSICIAN TO GUY's hOSPITAL.

Received February 9th-Read April 25th, 1893.

During the last few years much has been said and written about the treatment of chronic parenchymatous nephritis and chronic interstitial nephritis. The discussion has turned mainly on two points-drugs and diet. Iodide of potassium, lactate of strontium, fuchsin, tannin, benzoic acid, nitric acid, extract of secale cornutum, bromo-benzol, and acetate of lead have all been tried, and no one of these has gained any permanent hold upon the good opinion of a large number of the profession; perhaps the most popular is iodide of potassium. From my own experience I think that lactate of strontium will sometimes diminish the albuminuria, but I have been unable to detect that the condition of the patient is in any 
other respect altered by taking it. However, I do not propose this evening to deal with drugs, but to confine myself entirely to the question of diet in chronic Bright's disease.

I might be the whole evening quoting references to this subject, so I shall have to content myself with giving only the more important. The matter was discussed at the ninth Congress of Medicine ${ }^{1}$ held at Vienna in 1890. It was introduced by Senator. He did not say much about chronic interstitial nephritis, but he strongly recommended milk diet for the chronic parenchymatous form, and if milk disagreed he advised buttermilk, koumis, or kef; or if these could not be obtained, fish or fowl.

At the tenth International Medical Congress held at Berlin in $1890^{2}$ the subject was discussed at great length. Lépine introduced it, and said he thought milk was the ideal diet, for it replaces the albumen that the patient loses, all its nitrogen is absorbed and used, it does not irritate the kidneys, it is diuretic, and it does not contain any toxic substances, but aids their elimination. He, however, admitted that patients quickly get disgusted with milk, and therefore he also allows vegetables and farinaceous foods.

Grainger Stewart spoke next, and stated that an abundant diet of ordinary food increased the urea and albumen passed, a purely milk diet increased the flow of urine, diminished the discharge of albumen, and in some cases increased that of urea. The best results were obtained by a diet composed largely of milk, but also in part of bread, potatoes, sugar, and butter. Sometimes the milk diet manifestly disagreed with the patient, increased his renal symptoms, and at the same time rendered him uncomfortable and dyspeptic. Milk diet he considered to be especially useful in cases of inflammation of the tubules, and as the case approaches the chronic interstitial variety, so in proportion is milk

1 'Centralblatt f. klin. Medo', 1890.

2 'Verhandlungen des X Intern. Med. Congresses,' Bd. ii, Abtheilung 5. 
less valuable. Fuller details of Grainger Stewart's opinions will be found in his work on albuminuria. ${ }^{1}$ Three cases of parenchymatous nephritis (p. 203) were carefully tested with different diets. In the first ordinary diet, milk diet, and low diet brought out essentially the same result, both in respect to urea and albumen. In the second case it was somewhat difficult to judge the results, for the patient was steadily recovering, but on the whole milk and low diets were better than ordinary diets, and low diet was the best of all. In the third case the diet made no difference to the amount of urine nor to its specific gravity, and it hardly affected the urea, but the albumen diminished under milk, and continued to do so on low diet. The author believes that these experiments do not warrant our arriving at any general conclusion, although they to some extent support the view that milk or low diet is better suited to cases of parenchymatous nephritis than ordinary or ample diet. One case in which an acute attack of Bright's disease supervened upon the chronic form was dieted with different diets, but no corresponding effect was discernible upon the quantity of urine or urea, and the albuminuria was certainly not diminished by the milk. And, lastly, the conclusion was reached that in the cirrhotic form of Bright's disease the diet is of less importance than in tubal inflammation.

Drs. Sparks and Mitchell Bruce ${ }^{2}$ have read an important paper on the effect of diet, rest, exercise, \&c., on a case of chronic nephritis. They came to the conclusion that the amount of albumen was diminished by an absolute milk diet, which, however, produced a sensation of unsatisfied hunger and sinking, and by an absolute nonnitrogenous diet, and that the milk diet caused a much diminished secretion of urea. The exact form of chronic nephritis from which this patient was suffering was perhaps doubtful.

1 'Lectures on Important Symptoms. II. Albuminuria.'

2 'Trans. Roy. Med.-Chir. Soc.,' vol. lxii. 
Rosenstein ${ }^{1}$ is much more liberal in his dietetics than most authors, for, provided that the digestive functions are good, he allows milk, eggs, meat, green vegetables, and good red Bordeaux to patients with chronic nephritis.

Osler ${ }^{2}$ advises for acute Bright's disease a diet consisting of milk, buttermilk, gruel, barley water, chicken broth, beef-tea; and considers that, if possible, the patient should be kept on a strictly milk diet. For chronic parenchymatous nephritis he recommends a similar dietary, and he thinks that no particular diet is necessary for patients with chronic interstitial nephritis so long as whatever they have is taken in moderation.

Fenwick ${ }^{3}$ states that patients with chronic Bright's disease should eat but little meat and plenty of vegetables and fruit, but he quotes Niemeyer as strongly recommending a milk diet. With regard to acute Bright's disease, he points out that the majority of French writers advise any light diet, but in Germany a purely or almost purely milk diet is given.

Sir George Johnson ${ }^{4}$ says that in cases of acute albuminuria, if the albumen has disappeared on milk diet, the addition of solid food will cause it to reappear ; and with regard to more chronic cases he advises milk diet, and relates the case of a man who lived on milk for a long time with great benefit.

Ralfe, ${ }^{5}$ too, mentions a case of chronic nephritis in which much good accrued from a milk diet.

Sir William Roberts ${ }^{6}$ simply says that milk agrees well with patients suffering from chronic Bright's disease, and that they may partake freely of it. For the acute disorder he advises light farinaceous diet.

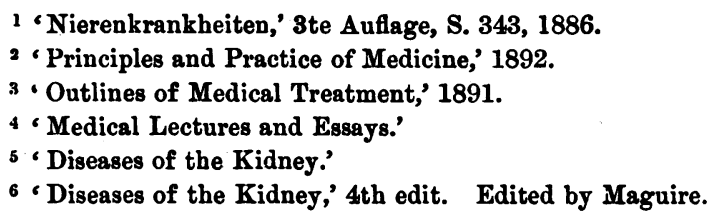


Dickinson ${ }^{1}$ would restrict patients to the smallest amount of animal food on which they will thrive.

Labadie-Lagrave ${ }^{2}$ does not very strongly advise milk, but thinks it is most useful for patients suffering from a large white kidney.

Carter, ${ }^{3}$ in his lectures on uræmia, states that the urine of animals fed on milk was less poisonous than that of those fed on other diets, and he recommends a milk diet in Bright's disease.

Zasiadko made a series of experiments from which he concluded that in chronic Bright's disease, on vegetable foods, the albumen decreased, arterial tension sank, the dropsy increased, the pulse became slower and weaker, the appetite was lost, and the general state of the patient was worse; but on animal diet the albumen rose in quantity, the pulse was stronger and its tension was higher, the cdema diminished, the amount of the urine, its proportion of solids, and its specific gravity all increased, and the general state of the patient improved. With a mixed diet intermediate results were obtained. Therefore for interstitial nephritis he advises chiefly animal food, but for the parenchymatous form he recommends vegetable diet.

The subject was discussed at a recent meeting of the Académie des Sciences. Dujardin-Beaumetz said that the object of treatment should not be so much to affect the albuminuria as to diminish the risk of poisoning by toxic substances; he therefore suggested that all food should be fresh-apparently assuming that the toxines. which cause uræmia are the same as those which develop in decomposing food. Consequently he forbids fish, game, oysters, and cheese. He regards milk as very valuable, but advises that it should be sterilised, and says meat should be thoroughly cooked. He never saw albuminuria increased by eggs.

1 'Diseases of the Kidney.'

2 ' Urologie clinique et maladies des reins,' 1888.

3 ' British Med. Journal,' Sept. 1st, 1888.

' ‘ British Med. Journal, Epitome,' Nov, 8th, 1890. 
I might quote many other authors, but I think I have referred to sufficient to show that they are by no means unanimous as to the best diet to give patients suffering from chronic Bright's disease. For this reason, and also because many have used too few cases for the results to be conclusive, and others have relied largely on a priori considerations, it seemed to me worth while to carefully analyse the urine and note the symptoms in a series of cases. We know so little that is certain about the cause of the serious symptoms of Bright's disease that it is only by actual trial that we can find out whether any particular diet is valuable.

Milk is very frequently recommended, and it has been claimed that it will do good for the following reasons :

1. It is said to diminish the amount of albumen. In the first place, the figures I shall give later on will show that this is very far from being always true, at any rate in chronic interstitial nephritis; and some of Grainger Stewart's cases point in the same direction, for on ordinary, large, milk, or low diet the albuminuria remained unchanged, and even partaking abundantly of eggs did not increase it. Such experiences as these mean either that the reported cases in which it is said that the albuminuria was diminished by a milk diet belong to a different category, or else that they were improving in this respect at the time that the milk diet was started.

Then, secondly, even if milk did decrease the albuminuria, we have in many cases no proof that this is of any benefit. Patients who are very ill may lose only one or two grammes of albumen a day in the urine. This cannot of itself be of much importance; the absorption from the intestine of a very little more albuminous material would, if not lost in some excretion, quickly make up the deficiency. Then, again, people who suffer from cyclic albuminuria are often none the worse for it, nor does the loss of albumen in other ways, as by epistaxis, or by means of a discharge of pus, produce any symptoms comparable to those of Bright's disease. 
Indeed, the majority of persons who pass albumen in their urine have not got Bright's disease at all, but are suffering from heart disease, pyuria, specific fevers, \&c. Lastly, albuminuria is probably to a large extent only a local sign indicating disease of the secreting renal epithelium, and not a general blood condition. All these considerations indicate that even in cases of Bright's disease in which the loss of albumen is considerable, this of itself is not really quite so important as is usually thought. Surely if it were, restricting the diet to food containing less albumen than ordinary diet ought to be harmful to the patient, for not only would he be losing more albumen than in health, but he would be taking in less, and I shall presently show that-if we may assume that when more proteid is taken by persons suffering from Bright's disease more is absorbed-even when full diet increases albuminuria, the increased amount of proteid taken very much more than compensates for the increased albumen passed in the urine, and in some cases of Bright's disease the albuminuria is even less on full than on milk or farinaceous diets. No doubt the restriction of the saccharine food in diabetes would by analogy lead us to restrict the albuminous food in albuminuria, but analogical reasoning of this sort is most fallacious. I feel quite sure that the significance of albuminuria in Bright's disease is over-estimated, and that treatment directed immediately to it is unsound, especially when, as in the case of milk diet, although it frequently fails to diminish the amount of albumen passed, it often sets up loathing and disgust.

2. Some authors urge that milk is easily digested and absorbed. Often this is directly contrary to fact. Many writers have noticed, and I have often observed, that patients who have chronic Bright's disease and are fed solely upon milk often suffer from indigestion, and, as just mentioned, they get to positively loathe the milk, which also has the additional disadvantage that it leads to constipation.

3. It is stated that milk does not irritate the kidneys. But before this statement can have any value it must be 
shown that ordinary food does irritate them, and this has not yet been done. It is curious that if milk is such a particularly bland and unirritating substance to the kidneys, these organs should in young children be so frequently streaked with urates.

4. Milk is often said to be diuretic. For instance, the patient whose case is related by Drs. Sparks and Mitchell Bruce passed more urine on a milk diet than on ordinary diet together with a large amount of water; but as he passed more urine in this combination than on ordinary diet alone, it is highly probable that the diuretic effect of the milk was in part due to the quantity of water in it. Some of the cases I shall relate show that milk is usually, but not invariably, diuretic. Of Grainger Stewart's cases milk did not act as a diuretic in those with parenchymatous nephritis, nor did it in the chronic cases. Thus we see that milk is neither a powerful nor a certain diuretic ; and we must remember that even if it were, it is doubtful whether it would be a good thing to give diuretics in Bright's disease.

(5) Lépine has urged that milk is beneficial for Bright's disease because it contains no toxic substances. But, for all we know, it may contain poisonous substances, which although excreted in health are retained in the blood in Bright's disease. His supposition that it aids the elimination of toxic substances in Bright's disease is without a shadow of proof. It seems to me futile to argue in this way about the toxine of Bright's disease when we do not know what it is.

The view that a diet containing very little proteid is beneficial for Bright's disease is probably due to a lingering survival of the false belief that the urea which is not excreted in Bright's disease is the cause of the symptoms of uræmia.

We thus see that all the a priori considerations which have been put forward as reasons for giving milk in chronic Bright's disease have in themselves no value, and similar objections could be urged against the reasons 
which have led to the belief that other particular diets would be beneficial. Therefore all that is left to us is to examine cases, and I propose now to analyse the ten cases, all under my own care, which form the basis of this paper. The following is the composition of the diets employed.

Milk diet consists of milk 3 pints a day.

Farinaceous diet consists of bread 12 oz., butter 1 oz., milk 2 pints, beef tea 1 pint a day. (The beef tea is often omitted.)

Full diet consists of bread 12 oz., butter 1 oz. milk $\frac{1}{2}$ pint, potatoes $\frac{1}{2}$ lb., meat $6 \mathrm{oz}$. a day. Rice pudding made with milk $\frac{1}{2} \mathrm{lb}$. is allowed on alternate days; when this is not given the patient has $\frac{1}{2}$ pint of mutton broth. The patients whose cases are narrated in this paper nearly always had rather over a pint of milk instead of the above half-pint. Tea and sugar are allowed with both farinaceous and full diets. The amount of milk taken with the tea is small, and as it is the same in both diets it may in contrasting them be neglected.

The following table shows the amount of proteid in each diet :

Milk Diet.

Proteid.

Milk 3 pts. $=61.5 \mathrm{oz}$. (milk contains $4 \%$ proteid) $=2.46 \mathrm{oz}$.

\section{Farinaceous Diet.}

Bread 12 oz. (containing $8 \%$ proteid) $\ldots \quad \ldots=0.96 \mathrm{oz}$.

Milk $41 \mathrm{oz}$. (containing $4 \%$ proteid) $\quad \ldots \quad \ldots=1.64 \mathrm{oz}$.

Full Diet.

$$
\overline{2 \cdot 60 \mathrm{oz}} \text {. }
$$

Bread 12 oz. (containing $8 \%$ proteid) $\quad \ldots \quad \ldots \quad=0.96 \mathrm{oz}$.

Meat 6 oz. (containing 18\% proteid) $\ldots . . . .=1.08 \mathrm{oz}$.

Milk rather over $1 \mathrm{pt}$. (containing $4 \%$ proteid) $\ldots=1.0 \mathrm{oz}$.

Rice pudding with milk, $\frac{1}{2} \mathrm{lb}$. (about 5.5\% proteid) $=0.44 \mathrm{oz}$.

Milk diet contains therefore 1076 grains of proteid.

$3 \cdot 48$ oz.

$\begin{array}{lllll}\text { Farinaceous diet } & & 1137 & & \\ \text { Full diet } & " & 1522 & \text { " }\end{array}$

When any of the patients showed signs of uræmia they

1 On the days when rice pudding is not given there will not be quite so much proteid taken. 
were treated with subcutaneous injections of nitrate of pilocarpine, vapour-baths, and compound jalap powder or compound elaterium powder. Eight were instances of chronic interstitial nephritis. Two were examples of chronic parenchymatous nephritis; it is possible that these two may have had some lardaceous disease of their kidneys.

We may analyse the results under the following heads: -(1) The quantity of urine passed. (2) Its specific gravity. (3) The amount of albumen. (4) The amount. of urea. (5) The general condition of the patient.

\section{The Quantity of Urine Passed.}

(A) Eight Cases of Interstitial Nephritis.

Milk diet.-Cases 2, 3, 6, and 7.

Case 2 passed 42 oz. a day on milk diet, against 40 on full, and 37 on full with chop and egg.

Case 3 passed $55 \mathrm{oz}$. a day on milk diet, against 33 on farinaceous, 35 on farinaceous with chicken, and 33 on farinaceous with chicken and fish.

Case 6 passed 88 oz. a day on milk diet against 100 on farinaceous, and 52 on full.

Case 7 passed 49 oz. a day on milk diet, against 42 on full, and 40 on full with an egg.

Result.-In three out of four cases more urine (viz. about 3 or 4 oz., about 20 oz., about 8 oz.) was passed daily on a milk diet than on other diets; in the remaining case $12 \mathrm{oz}$. a day less were passed upon a milk diet than upon farinaceous. But Cases 2 and 3 were fatal, and perhaps the lessened quantity of urine on other diets was due to the fact that the patients were nearing their end when taking these diets. On the whole it appears that milk is sometimes but not always a mild diuretic in chronic interstitial nephritis. There is, however, but little opportunity in these cases for contrasting it with farinaceous diet.

Farinaceous diet.-Cases 1, 3, 4, (two trials), 5, 6, and 8, 
Case 1 passed 75 oz. a day on farinaceous diet, against 57. oz. on full.

Case 3 passed $33 \mathrm{oz}$ a day on farinaceous diet, against $55 \mathrm{oz}$. on milk, $\mathbf{8 5} \mathrm{oz}$. on farinaceous with chicken, and $33 \mathrm{oz}$. on farinaceous with chicken and fish.

Case 4 (first trial) passed 47 oz. a day on farinaceous diet, against $43 \mathrm{oz}$. previously on farinaceous with fish, and $39 \mathrm{oz}$. previously on full, and $50 \mathrm{oz}$. subsequently on farinaceous with fish, and $29 \mathrm{oz}$. on farinaceous with chicken.

Case 4 (second trial) passed $27 \mathrm{oz}$ a day on farinaceous diet, against $29 \mathrm{oz}$. previously on farinaceous with chicken, $21 \mathrm{oz}$. subsequently on full, and $20 \mathrm{oz}$. on farinaceous with fish.

Case 5 passed 36 oz. a day on farinaceous diet, against 20 oz. previously on farinaceous with milk, 29 oz. on farinaceous with fish, and $55 \mathrm{oz}$. subsequently on full.

Case 6 passed $100 \mathrm{oz}$. a day on farinaceous diet, against $88 \mathrm{oz}$. previously on milk and $52 \mathrm{oz}$. subsequently on full.

Case 8 passed 36 oz. a day on farinaceous diet, against $33 \mathrm{oz}$. subsequently on farinaceous with fish.

Result.-Contrast with milk. In one case less urine was passed on farinaceous diet (viz. $20 \mathrm{oz}$.), and in one case more (viz. 12 oz.).

Contrast with full diet. In four cases more urine was passed on farinaceous diet (viz. 18 oz., 8 oz., 6 oz. 48 oz.), and in one case less (viz. 19 oz.).

It appears, therefore, that usually more urine is passed upon farinaceous diet than upon full diet,-often, indeed, considerably more, but there is not much to choose between farinaceous and milk.

\section{Farinaceous Diet combined with Fish or Chicken.}

In addition to the cases just mentioned, we have Case 1 (second trial); in this $40 \mathrm{oz}$. a day were passed on farinaceous diet, against $50 \mathrm{oz}$. when fish and two eggs were added, and $41 \mathrm{oz}$. when fish, two eggs, and chop were added. In Case 3 also there was a slight increase 
on the addition of chicken, but more on the addition of chicken and fish. In Case 4 the addition of chicken or fish sometimes increased, sometimes diminished, the quantity secreted. In Cases 5 and 8 rather less was passed when fish was added to the farinaceous diet. We learn, therefore, that the addition of fish or chicken or both to the farinaceous diet has very little influence on the amount of urine secreted, and that the influence is uncertain.

$$
\text { Full Diet.-Cases 1, 2, 4, 5, 6, } 7 .
$$

Case 1 passed $57 \mathrm{oz}$. a day on full diet, against $75 \mathrm{oz}$. on farinaceous.

Case 2 passed $40 \mathrm{oz}$. a day on full diet, against $42 \mathrm{oz}$. on milk.

Case 4 passed $39 \mathrm{oz}$. a day on full diet, against $43 \mathrm{oz}$. previously on farinaceous with fish, and $47 \mathrm{oz}$. subsequently on farinaceous, and on a second occasion, 21 oz. on full against $26 \mathrm{oz}$. previously on farinaceous, and $20 \mathrm{oz}$. subsequently on farinaceous with fish.

Case 5 passed $55 \mathrm{oz}$. a day on full diet, against $36 \mathrm{oz}$. previously on farinaceous.

Case 6 passed $52 \mathrm{oz}$. a day on full diet, against $100 \mathrm{oz}$. previously on farinaceous, and $88 \mathrm{oz}$. on milk.

Case 7 passed $42 \mathrm{oz}$. a day on full diet, against $49 \mathrm{oz}$. previously on milk.

Result.-In six instances the urine was distinctly less on a full diet than on farinaceous or milk, the decrease being 18,2 , about $6,5,48,7 \mathrm{oz}$. in each respective case. In two cases there was an increase, but in one of these (Case 2) the urine, which was $21 \mathrm{oz}$. on a full diet, became $20 \mathrm{oz}$. on farinaceous and fish, but this trifling difference is probably unimportant, as the patient was dying. In the other case there was an increase of $19 \mathrm{oz}$. on a full diet, but in this case the patient was improving in all respects. We may conclude, therefore, that as a rule, less urine is passed upon full than upon milk or farinaceous diets. 
Full Diet combined with Chop or Eggs.

Case 2. On the addition of a chop and sometimes an egg to full diet, $5 \mathrm{oz}$. less urine a day were secreted than on milk diet, and $3 \mathrm{oz}$. less than on full.

Case 7. On the addition of .an egg to full diet, $2 \mathrm{oz}$. less urine were secreted than on full diet only.

When, therefore, chop or eggs were added to full diet, less urine was secreted.

General result. - We may, I think, conclude that usually, in chronic interstitial nephritis, more urine is secreted upon milk and farinaceous diets than upon full diet.

(в) Two Cases of Chronic Parenchymatous Nephritis.

Case 9. 'The secretion was $74 \mathrm{oz}$. a day on farinaceous diet; it fell to $35 \mathrm{oz}$. on full.

Case 10. The secretion was $72 \mathrm{oz}$. a day on farinaceous diet ; it fell to $65 \mathrm{oz}$. on full, rose again to $69 \mathrm{oz}$. on milk, but fell again to $50 \mathrm{oz}$. on full.

Result.-The results just enunciated for chronic interstitial nephritis appear to apply to the parenchymatous variety also.

\section{The Specific Gravity of the Urine.}

The diets are arranged in an ascending scale, that on which the specific gravity of the urine was lowest being placed first.

\section{(A) Eight Cases of Interstitial Nephritis.}

Case 1. (First trial,) farinaceous, full. (Second trial,) farinaceous and farinaceous with fish and eggs equal, farinaceous with chop, eggs, and fish.

Case 2. Milk, full, and full with chop and egg equal.

Case 3. Milk, farinaceous, farinaceous with chicken or fish.

Case 4. Farinaceous with fish, farinaceous, full, farinaceous with fish, farinaceous with cocoa and full equal, farinaceous with fish, farinaceous with chicken. 
Case 5. Full, farinaceous with milk, farinaceous with fish, farinaceous.

Case 6. Farinaceous, milk, full.

Case 7. Milk, full with egg, full.

Case 8. Farinaceous, farinaceous with fish.

Result.-We may, I think, conclude that the diet has no certain influence on the specific gravity of the urine in chronic interstitial nephritis, but that on the whole it is lower on milk and farinaceous diets than on full diet.

(в) Two Cases of Chronic Parenchymatous Nephritis.

Case 9. Farinaceous, full.

Case 10. Farinaceous, milk, full.

Result.-Probably the same is true here also.

\section{The Amount of Albumen passed. ${ }^{1}$}

(A) Eight Cases of Interstitial Nephritis.

Milk Diet.-Cases 2, 3, 6, and 7.

Case 2 passed 8.6 grains a day on milk diet, against 9 grains on full with chop and sometimes egg. (The figure obtained for the three days on full diet is so widely different, that as the days are so few it had better be neglected.)

Case 3 passed 24.3 grains a day on milk diet, against 17.8 grains on farinaceous, 23.8 grains on farinaceous with chicken, and 25 grains on farinaceous with chicken and fish.

Case 6. After the first day in the hospital there was no albumen on milk, farinaceous, or farinaceous with fish diets.

1 The albumen was always estimated by means of Esbach's tubes. The results are therefore too low ('Clinical Diagnosis,' v. Jaksch, translated by J. Cagney, 2nd edit., p. 263), but my object has not been to ascertain precisely the weight of albumen passed on different diets, but to find out whether altering the diet altered the amount of albumen passed. As Esbach's tubes were used consistently throughout each case they will show this, even although the total amount of albumen registered by them is too low. The exact estimation of albumen is very laborious, and is hardly necessary, as the degree of albuminuria is of very little importance in Bright's disease. 
Case 7. No quantitative estimations of albumen were made, but the patient first had milk diet, then full, then full with egg; but the albumen, which was most on milk diet, steadily diminished on the other diets.

Result.-From these cases we learn that milk diet has little or no effect in reducing albuminuria. Sometimes, indeed, more albumen is passed upon milk than upon other diets. When we consider that full diet contains about 400 grains more proteid than either milk or farinaceous, the conclusion seems inevitable that the diet least suitable for compensating for the loss of albumen to the body owing to that in the urine is a milk diet.

Farinaceous Diet.-Cases 1, 3, 4 (two trials), 5, 6, 8.

Case 1 passed 78 grains a day on farinaceous diet, against 23 grains subsequently on full.

Case 3 passed $17 \cdot 8$ grains a day on farinaceous diet, against $24 \cdot 3$ grains on milk, and about 24 grains on farinaceous with chicken or fish.

Case 4. (first trial) passed $39 \cdot 3$ grains a day on farinaceous diet, against 38.3 grains previously on full, 16.8 grains previously on farinaceous with fish, and 37.5 grains on farinaceous with fish or chicken.

Case 4 (second trial) passed 60 grains a day on farinaceous diet, against previously the amounts just mentioned; and subsequently 33 grains on full, and 16.8 grains on farinaceous with fish.

Case 5 passed 162 grains a day on farinaceous diet, against 76 grains on farinaceous with milk, 170 grains on farinaceous with fish, and 66 grains on full.

Case 6 passed no albumen on either farinaceous or full diet.

Case 8 passed 327 grains a day on farinaceous, against 513 grains on farinaceous with fish.

Result.-Contrast with milk: In the one case in which farinaceous can be contrasted with milk diet 6.5 grains of albumen less each day were passed on farinaceous than on milk. 
Contrast with full : In the four cases in which farinaceous can be contrasted with full diet, 55, 1, 27, and 96 grains of albumen more each day were passed on farinaceous than on full. The very important result, therefore, follows that albuminuria in chronic interstitial nephritis is much more severe on a farinaceous than on a full diet. As the full diet is much more rich in proteid than farinaceous, the compensation for the albumen lost by the urine is probably very much better on full than on farinaceous diet.

Farinaceous combined with Fish or Ohicken.

In addition to the cases just mentioned we have Case 1 (second trial) in which 485 gruins of albumen a day were passed on farinaceous diet, against 671 grains on farinaceous with fish and two eggs, and 690 on farinaceous with fish, two eggs, and chop. It will be noticed that in some cases on the addition of fish or chicken the albuminuria increased, in others it diminished; but it increased oftener, and increased more than it decreased.

$$
\text { Full Diet.-Cases 1, 2, 4, 5, 6, } 7 .
$$

Case 1 passed 23 grains a day on full diet, against 78 grains on farinaceous.

Case 2. For the reason already mentioned the three days on full diet are not available for contrast.

Case 4 passed 38.3 grains a day on full diet, against 16.8 grains previously on farinaceous with fish, and 39.3 grains subsequently on farinaceous; and on a second occasion 33 grains a day on full diet, against 60 grains previously on farinaceous, and 16.8 grains subsequently on farinaceous with fish.

Case 5 passed 66 grains a day on full diet, against 162 grains previously on farinaceous.

Case 6. No albumen on either full or farinaceous diets.

Case 7. The albumen was less on full diet than on milk.

Result.-In only two instances was there any increase of albumen on full diet; both these occurred in Case 4, once soon after admission and once before death : it is 
highly probable that these two instances are not of much importance, for in the same case when the conditions were steadier there was a considerable diminution of albumen on full diet. In all the other cases of chronic interstitial nephritis the albumen was less on a full diet than on any other. The importance of this has already been pointed out.

\section{Full Diet combined with Chop or Eggs.}

Case 2. The albumen was practically the same on full diet with chop, and sometimes egg, as on milk.

Case 7. The albumen continued to decrease when the egg was added to the full diet.

Result.-These cases appear to show that chop or eggs do not increase the albuminuria in chronic interstitial nephritis.

(в) Two Cases of Chronic Parenchymatous Nephritis.

Case 9. In this nearly twice as much albumen was passed upon full diet as upon farinaceous.

Case 10. First occasion, nearly four times as much albumen was passed upon full diet as upon farinaceous. Second occasion, rather less (about $\frac{1}{8}$ ) was passed on full diet than upon milk.

Result.-It appears that in chronic parenchymatous nephritis the albuminuria is more profuse upon a full diet than upon farinaceous. But full diet contains nearly 400 grains a day more proteid than farinaceous. Now the increased albuminuria on full diet was, in Case 9, 81 grains a day, and in Case 10, 202 grains a day, so that both these patients were probably far better able to compensate for the loss of albumen by the urine upon a full diet than upon farinaceous. This, of course, could not be proved unless the fæces were analysed, but as the full diet did not lead to diarrhca it is probable that as regards saving of albumen the patients were far better off on full diet than on any other. 
IV. The QUaNTITY of UREa Passed.

(A) Eight Cases of Interstitial Nephritis. Milk Diet.-Cases 2, 3, 6, and 7.

Case 2 passed 212 grains a day on milk diet, against 176 on full.

Case 3 passed 352 grains a day on milk diet, against 266 on farinaceous, and 289 on farinaceous with chicken.

Case 6 passed 264 grains a day on milk diet, against 397 on farinaceons and 416 on full.

Case 7 passed 363 grains a day on milk diet, against 338 on full, and 344 on full with an egg.

Result.-In two cases much more urea was passed on a milk than upon other diets, but both these cases were going downhill, and as the milk happened to be the first tried, it is quite possible that the diminution in the excretion of urea simply meant that the patient was nearing his end. In one of the other two cases the urea was 133 grains a day less on milk than on farinaceous, and 152 less on milk than on full; in the other the diet made very little difference to the excretion of urea. On the whole it is difficult to say from these cases what is the effect of milk diet on the excretion of urea.

Farinaceous Diet.-Cases 1, 3, 4 (two trials), 5, 6, 8.

Case 1 passed 212 grains a day on farinaceous diet, against 308 on full.

Case 3 passed 266 grains a day on farinaceous diet, against 352 on milk, 289 on farinaceous with chicken, and 283 on farinaceous with chicken and fish.

Case 4 passed 248 grains a day on farinaceous diet, against 223 on full, 275 on farinaceous with fish, and 192 on farinaceous with chicken. On a second occasion 215 grains a day were passed on farinaceous, against 153 on full and 131 on farinaceous with fish.

Case 5 passed 225 grains a day on farinaceous diet, 
against 138 on farinaceous with milk, 294 on farinaceous with fish, and 314 on full.

Case 6 passed 397 grains a day on farinaceous diet, against 264 on milk, and 416 on full.

Case 8 passed 209 grains a day on farinaceous diet, against 243 on farinaceous with fish.

Result.-Contrast with milk : In the one case in which this is possible 133 grains a day more urea were passed upon farinaceous than upon milk diet. Contrast with full : In three cases in which this contrast can be made 96,19 , and 89 grains a days less were passed upon farinaceous than on full, and in two cases 25 and 62 grains a day more urea were passed upon farinaceous than upon full. We thus see that in contrasting full with farinaceous diet there is no certain influence upon the output of urea.

Farinaceous combined with Fish or Chicken.

In addition to the cases just mentioned we have Case 1 (second trial), in which 212 grains of urea a day were passed on farinaceous diet, against 376 grains on farinaceous with fish and two eggs, and 235 grains on farinaceous with fish, eggs, and chop. This case shows how uncertain is the effect of adding proteids to farinaceous diet; and Case 4 shows this even more markedly, for sometimes the addition caused an increase and sometimes a diminution of the urea excreted. Cases 3,5 , and 8 passed more urea when proteids were added to farinaceous diet than they did on farinaceous diet only. Although it is not a constant result, the addition of proteids to farinaceous diet usually increases the excretion of urea.

$$
\text { Full Diet.-Cases 1, 2, 4, 5, 6, } 7 .
$$

Case 1 passed 308 grains a day on full diet, against 212 grains on farinaceous.

Case 2 passed 176 grains a day on full diet, against 212 grains on milk.

Case 4 passed 223 grains a day on full diet, against 
248 grains on farinaceous, 275 grains on farinaceous with fish, and 192 grains on farinaceous with chicken. On a second occasion 153 on full, against 215 grains on farinaceous, 154 on farinaceous with cocoa, and 131 on farinaceous with fish.

Case 5 passed 314 grains a day on full diet, against 225 grains on farinaceous, 294 grains on farinaceous with fish, and 138 grains on farinaceous with milk.

Case 6 passed 416 grains a day on full diet, against 397 grains on farinaceous, and 264 grains on milk.

Case 7 passed 338 grains a day on full diet, against 363 grains on milk.

Result.-Contrast with milk : In both cases in which this could be made, actually less urea was passed upon full diet (viz. 36 and 25 grains a day) than upon milk.

Contrast with farinaceous: In three cases more urea (viz. 96, 89, and 19 grains a day) was passed upon full diet than upon farinaceous, but in two cases less urea (viz. 25 and 62 grains a day) was passed upon full diet. The effect, therefore, of diet upon the excretion of urea in chronic interstitial nephritis is most uncertain, for it by no means follows-in fact, the reverse is often true, -that more proteid in the food means more urea excreted.

\section{Full Diet combined with Chop or Eggs.}

Case 2. The urea was a few grains less a day when chop and egg were added to the full diet than on full diet only.

Case 7. The urea was a few grains more every day when an egg was added to the full diet than upon a full diet only.

Result.-As far, therefore, as these two cases go, the addition of a chop or egg to the full diet has no noteworthy effect.

(в) Two Cases of Chronic Parenchymatous Nephritis.

Case 9. The daily excretion of urea was 382 grains on farinaceous diet, against 302 grains on full. 
Case 10. The urea excreted was 421 grains a day on milk diet; 380 grains on one set of days, and 339 grains on another set on full; and 269 grains a day on farinaceous.

Result.-In this variety of nephritis, as in chronic interstitial nephritis, the urea excreted is often less the more proteid the diet contains.

\section{The General Condition of the Patient.}

The points to which attention was particularly directed in estimating the general condition of the patient were his strength and feeling of well-being, whether he was listless and liked to remain in bed, or whether he wished to get up; his breathlessness and the condition of his circulation.

\section{(A) Eight Cases of Interstitial Nephritis.}

Case 1 (first admission). For the first nine days on farinaceous diet, for the remaining sixteen on full. $\mathrm{He}$ left the hospital having improved considerably in every respect.

Case 1 (second admission). He always felt better and stronger on farinaceous diet with meat and egg added, than on farinaceous.

Case 2. Although this patient ultimately died from cardiac failure associated with valvular disease, he most undoubtedly felt better and stronger on abundant full diet than on milk.

Case 3. There is a note made when the patient had been for some days taking fish or chicken with his farinaceous diet, to say that he certainly felt better on this combination than on milk.

Case 4. The only time that this patient felt better and was able to be up and about was from May 7th to May 16th, for the first four days of which period he was on farinaceous diet, and for the remainder of which he was on full diet. 
Case 5. Excepting for three days, when he had a little fish with his farinaceous diet, he had farinaceous only from May 25th to June 20th. From June 15th to June 20 th he had severe uræmic symptoms, for which he was treated in the usual way. On June 21st he was put on full diet; from this time he began to gradually improve. He remained on this diet till July 24th, when he was able to leave the hospital.

Case 6. The patient was kept on milk diet for the first three days, farinaceous for the next nine, and full for the last twelve. She steadily improved during the whole of her stay in the hospital.

Case 7. He was on milk diet for the first six days, and on full for the remaining twenty-one. He left the hospital very much better than on admission.

Case 8. This patient was quite certain that she felt very much better on farinaceous with fish than on farinaceous only.

Result.-The testimony of these eight cases is unanimous thai the patients feel better and stronger on full diet, or on farinaceous diet with fish or chicken added, than they do on milk or farinaceous diets. Four of the cases died, but the first was from bronchitis due to fog, the second from cardiac failure, both the aortic and mitral valves being diseased, the third had much bronchitis and some pneumonia, the fourth went steadily downhill although several diets were tried, but curiously during the greater part of the only period for which he mended a little he was taking full diet. We see, therefore, that there is no evidence from these cases that a fatal result is brought about by full diet or the addition of meat to farinaceous diet. Nor do these diets induce uræmia or any way weaken the patient. Case 5 is very striking in this respect, for although he had been taking farinaceous diet for nearly four weeks he developed severe uræmia ; the very day the symptoms of this abated he was put upon full diet, but they never returned, and he left the hospital greatly relieved. Not only has full diet no tendency to 
produce uræmia, but the patients always feel better and stronger on it, or when meat is added to their farinaceous diet. I have often seen this in other cases than those here recorded; some have been instances of interstitial, some of parenchymatous nephritis. Frequently the patients implore and beg for some meat, and my experience is that farinaceous diet is most unpopular in chronic Bright's disease ; and, like many others, I have often seen an absolute loathing of milk such as is hardly met with in other maladies.

(в) Two Cases of Chronic Parenchymatous Nephritis.

Case 9. This patient did not seem to care what food he took.

Case 10. This patient was quite certain that he felt better on full diet than on milk or farinaceous.

Result.-These cases certainly, as far as they go, bear out the conclusions at which we had arrived concerning chronic interstitial nephritis.

General Conclusions as regards Chronic Bright's Disease.

We see that on the whole an ordinary full diet is the best for this malady, for-(1) It does not increase the liability to uræmia.

(2) The general condition of the patients improves upon it, and they feel stronger and their circulation is better when they are taking it than when they are on milk or farinaceous diet.

(3) A saving of albumen to the body is effected by it, for even if the output of albumen is increased, which it very often is not, more than sufficient extra proteid is taken on the full diet to compensate for any extra loss in the urine, assuming, and there is no evidence to the contrary, that more proteid is absorbed upon full diet than upon milk.

(4) The effect of diet on the excretion of urea is too uncertain to be any guide to us, but there is no evidence that in this respect full diet is harmful. 
(5) There is no evidence that full diet contains, or specially leads to the formation of any toxic principles which are harmful in chronic Bright's disease.

(6) This diet prevents the repugnance felt by these patients to farinaceous diet, and their loathing of milk.

The only thing against it is that rather less urine is passed upon full diet than upon milk or farinaceous diet. But this difficulty can be overcome by drinking an extra quantity of water daily, and it must be remembered that in many cases of chronic Bright's disease diuresis is already profuse. It may be well to point out that as the ten cases which form the basis of this paper were all patients who were sufficiently ill to require admission to the hospital, it is quite possible that some of the conclusions might not apply to patients who had Bright's disease in a mild form, or to those accustomed to over-eat themselves.

Clinical History of the Ten Cases of Chronic Bright's Diskase, with Analyses of the Urine in each.

CaSE 1. Chronic interstitial nephritis; fatal.-Charles P-, æt. 48, admitted into Guy's Hospital, July 29th, 1891. Clinical clerks, Messrs. G. F. Still and C. S. Pantin.

The patient has often attended at the out-patient department for bronchitis and dyspnœa. He was in the hospital under Dr. F. Taylor for this in November, 1890, and again under Dr. Goodhart in March, 1891, when his symptoms were thought to be due to chronic interstitial nephritis. Since he left the hospital he has had to get up in the night to pass his water, his feet and legs have swollen, and he has had much dyspnca.

On admission.-There are tophi in his ears. There is much dyspnœa together with physical signs of emphysema. The cardiac dulness extends to one inch outside the nipple. The pulse is not hard. He was discharged on August 30th, having improved considerably in all respects.

Second admission.- - He was readmitted on October 6th. At first, after he left the hospital last time, he seemed very 
well, and was able to continue his work as a travelling photographer. He got wet, and soon after that he noticed that his urine was very scanty, that his legs and abdomen began to swell considerably, and that he had much dyspnca.

On admission.-There was much œdema, and great dyspnca with râles and rhonchi over both lungs. Pulse 64, not hard. The diagnosis made was subacute Bright's disease supervening upon chronic interstitial nephritis. His chief trouble was the bronchitis and pleuritic effusion; the latter was relieved by aspiration. He always felt better and stronger when he was on full diet than farinaceous. It appeared that the dense fog which prevailed in December increased his bronchitis to a fatal extent.

Autopsy. - There was found chronic interstitial nephritis and a greatly hypertrophied heart. The lungs were emphysematous.

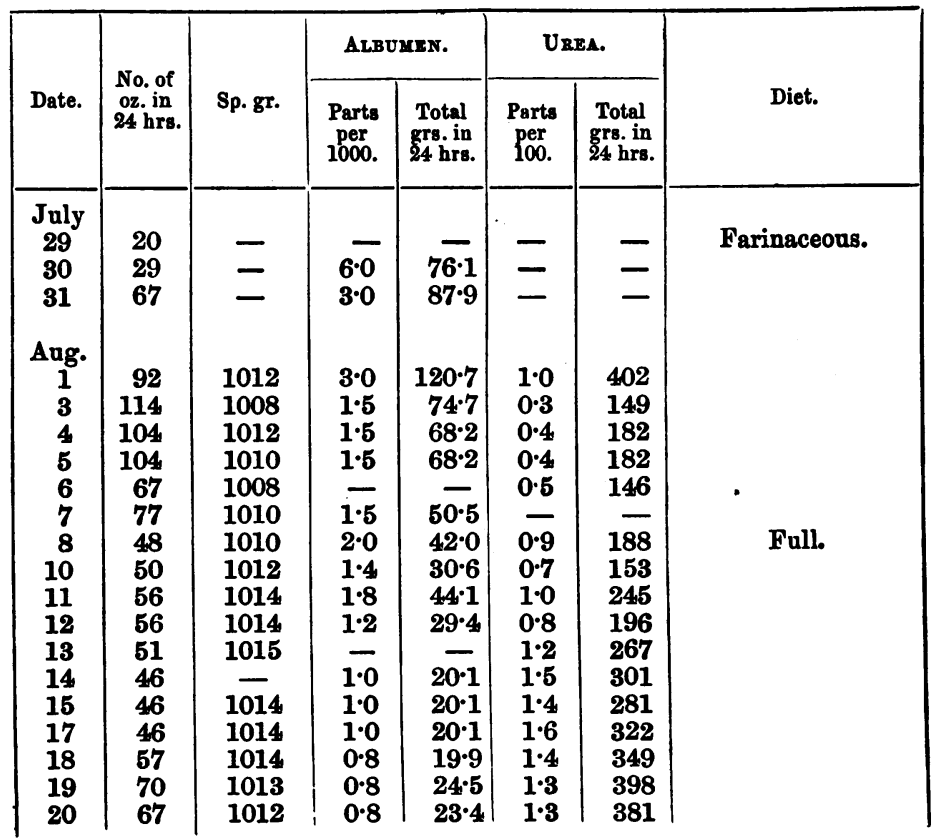




\begin{tabular}{|c|c|c|c|c|c|c|c|}
\hline \multirow[b]{2}{*}{ Date. } & \multirow{2}{*}{$\begin{array}{l}\text { No. of } \\
\text { oz. in } \\
24 \mathrm{hrs} \text {. }\end{array}$} & \multirow[b]{2}{*}{ Sp. gr. } & \multicolumn{2}{|c|}{ ALBUMEx. } & \multicolumn{2}{|c|}{ Unea. } & \multirow[b]{2}{*}{ Diet. } \\
\hline & & & $\begin{array}{c}\text { Parts } \\
\text { per } \\
1000 .\end{array}$ & $\begin{array}{l}\text { Total } \\
\text { grs. in } \\
24 \mathrm{hrs} .\end{array}$ & $\begin{array}{c}\text { Parts } \\
\text { per } \\
100 .\end{array}$ & $\begin{array}{c}\text { Total } \\
\text { grs. in } \\
24 \mathrm{hrs} .\end{array}$ & \\
\hline Aug. & & & & & & & \\
\hline 21 & 72 & 1015 & 0.8 & $25 \cdot 2$ & 1.5 & 472 & Full. \\
\hline $\begin{array}{l}23 \\
24\end{array}$ & $\begin{array}{l}70 \\
69\end{array}$ & $\begin{array}{l}1014 \\
1012\end{array}$ & $\begin{array}{l}0.5 \\
0.5\end{array}$ & $\begin{array}{l}15 \cdot 3 \\
15 \cdot 0\end{array}$ & 1.4 & $\begin{array}{l}428 \\
-\end{array}$ & \\
\hline 26 & 57 & 1013 & 0.5 & $12 \cdot 4$ & 1.3 & 324 & \\
\hline 27 & 57 & 1014 & 0.5 & $12 \cdot 4$ & $1 \cdot 3$ & 324 & \\
\hline Oct. & & & & & & & \\
\hline 6 & 一 & 1020 & $50 \cdot 0$ & - & $1 \cdot 6$ & - & Farinaceous. \\
\hline $\begin{array}{l}7 \\
8\end{array}$ & $\overline{28}$ & 1015 & $\begin{array}{l}30 \cdot 0 \\
30 \cdot 0\end{array}$ & $\overline{367.3}$ & $1 \cdot 8$ & $\overline{106}$ & \\
\hline 9 & $\begin{array}{l}28 \\
48\end{array}$ & $\begin{array}{l}1010 \\
1012\end{array}$ & 20.0 & $\begin{array}{l}367 \cdot 3 \\
420 \cdot 0\end{array}$ & $\begin{array}{l}1.6 \\
1.5\end{array}$ & $\begin{array}{l}196 \\
314\end{array}$ & \\
\hline 10 & 50 & 1012 & $20 \cdot 0$ & $437 \cdot 5$ & $1 \cdot 2$ & 262 & \\
\hline 12 & 64 & 1010 & $30 \cdot 0$ & $839 \cdot 6$ & 0.8 & 224 & \\
\hline 13 & 24 & 1020 & - & - & $1 \cdot 5$ & 157 & \\
\hline 14 & 16 & 1015 & - & - & $1 \cdot 2$ & 84 & \\
\hline 15 & 54 & 1015 & $22 \cdot 5$ & 511.5 & - & - & \\
\hline 16 & 36 & 1015 & $21 \cdot 2$ & $333 \cdot 9$ & $1 \cdot 6$ & 252 & \\
\hline 17 & 44 & 1019 & $22 \cdot 5$ & $433 \cdot 0$ & $1 \cdot 6$ & 308 & Farinaceous with fish \\
\hline 19 & 54 & 1016 & $30 \cdot 0$ & 708.4 & $2 \cdot 0$ & 472 & and two eggs. \\
\hline 20 & 48 & 1017 & $37 \cdot 5$ & $787 \cdot 4$ & $2 \cdot 2$ & 462 & \\
\hline 21 & 52 & 1016 & 33.5 & $762 \cdot 1$ & $2 \cdot 0$ & 465 & \\
\hline 22 & iit & 1016 & $25 \cdot 0$ & $699 \cdot 5$ & $2 \cdot 1$ & 587 & \\
\hline 23 & 36 & 1018 & - & - & $2 \cdot 1$ & 330 & \\
\hline 26 & 52 & 1018 & $27 \cdot 5$ & $625 \cdot 6$ & $1 \cdot 8$ & 409 & \\
\hline 27 & 48 & 1008 & $22 \cdot 5$ & $472 \cdot 4$ & 0.7 & 146 & \\
\hline 28 & 48 & 1016 & $40 \cdot 0$ & $840 \cdot 0$ & $1 \cdot 6$ & 336 & \\
\hline 29 & 64 & 1014 & $30 \cdot 0$ & $840 \cdot 0$ & $1 \cdot 6$ & 448 & \\
\hline 30 & 48 & 1014 & - & - & $1 \cdot 3$ & 273 & \\
\hline 31 & 50 & 1014 & $25 \cdot 0$ & 546.5 & $1 \cdot 3$ & 284 & \\
\hline Nov. & & & & & & & \\
\hline 2 & 72 & 1012 & $17 \cdot 5$ & $551 \cdot 2$ & $1 \cdot 1$ & 346 & Farinaceous with \\
\hline 3 & 48 & 1013 & - & - & $1 \cdot 5$ & 314 & fish, chop, and two \\
\hline 4 & 48 & 1011 & $20 \cdot 0$ & $420 \cdot 0$ & $1 \cdot 7$ & $\mathbf{3 5 7}$ & eggs. \\
\hline 5 & 40 & 1018 & - & - & $1 \cdot 7$ & 297 & \\
\hline 6 & 52 & 1017 & - & - & $1 \cdot 7$ & 386 & \\
\hline 7 & 28 & 1020 & $37 \cdot 5$ & $459 \cdot 3$ & $1 \cdot 8$ & 220 & \\
\hline 9 & 44 & 1019 & $50 \cdot 0$ & $962 \cdot 2$ & $1 \cdot 8$ & 346 & \\
\hline 10 & - & 1020 & $67 \cdot 5$ & - & $1 \cdot 1$ & - & \\
\hline 11 & - & 1016 & $37 \cdot 5$ & 一 & $2 \cdot 0$ & - & \\
\hline 13 & 40 & 1016 & - & - & $1 \cdot 8$ & 314 & \\
\hline 14 & 40 & - & $25 \cdot 0$ & $437 \cdot 2$ & - & - & \\
\hline 16 & 34 & 1018 & $32 \cdot 5$ & $483 \cdot 4$ & $2 \cdot 1$ & 312 & \\
\hline 17 & 40 & 1018 & $32 \cdot 5$ & $568 \cdot 7$ & $1 \cdot 8$ & 314 & \\
\hline 18 & 44 & 1018 & $50 \cdot 0$ & $962 \cdot 2$ & $1 \cdot 1$ & 211 & \\
\hline 19 & 44 & 1020 & $55 \cdot 0$ & $1058 \cdot 6$ & $1 \cdot 8$ & 346 & \\
\hline 20 & 44 & 1018 & $40 \cdot 0$ & 770.0 & $1 \cdot 1$ & 211 & \\
\hline 24 & 76 & 1014 & - & - & $1 \cdot 3$ & 432 & \\
\hline 25 & 72 & - & $70 \cdot 0$ & $2205 \cdot 0$ & - & - & \\
\hline 26 & 40 & 1015 & $45 \cdot 0$ & $787 \cdot 2$ & $1 \cdot 3$ & 227 & \\
\hline 30 & 36 & 1014 & $15 \cdot 0$ & $236 \cdot 1$ & - & & \\
\hline
\end{tabular}


VARIOUS DIETS IN BRIGHT'S DISEASE.

\begin{tabular}{|c|c|c|c|c|c|c|c|}
\hline \multirow{2}{*}{ Date. } & \multirow{2}{*}{$\begin{array}{l}\text { No. of } \\
\text { oz. in } \\
24 \text { lirs. }\end{array}$} & \multirow[b]{2}{*}{ Sp. gr. } & \multicolumn{2}{|c|}{ ALBUYKN. } & \multicolumn{2}{|c|}{ Urea. } & \multirow[b]{2}{*}{ Diet. } \\
\hline & & & $\begin{array}{c}\text { Parts } \\
\text { per } \\
1000 .\end{array}$ & $\begin{array}{l}\text { Total } \\
\text { grs. in } \\
\mathbf{2 4} \text { hrs. }\end{array}$ & $\begin{array}{c}\text { Parts } \\
\text { per } \\
100 .\end{array}$ & $\begin{array}{l}\text { Total } \\
\text { grs. in } \\
24 \mathrm{hrs}\end{array}$ & \\
\hline Dec. & & & & & & & \\
\hline 1 & 24 & 1018 & $55 \cdot 0$ & $557 \cdot 4$ & 1.8 & 188 & Farinaceous, with \\
\hline $\begin{array}{l}\mathbf{2} \\
\mathbf{3}\end{array}$ & $\begin{array}{r}8 \\
24\end{array}$ & $\begin{array}{l}1020 \\
1014\end{array}$ & $\begin{array}{l}\mathbf{5 2 \cdot 5} \\
\mathbf{5 2 \cdot 5}\end{array}$ & $\begin{array}{l}183 \cdot 7 \\
551 \cdot 2\end{array}$ & $\begin{array}{l}1 \cdot 2 \\
1 \cdot 6\end{array}$ & $\begin{array}{r}42 \\
168\end{array}$ & fish, chop, and two \\
\hline 4 & 68 & 1016 & $40 \cdot 0$ & $1190 \cdot 0$ & 1.7 & 506 & \\
\hline 5 & 16 & 1018 & 47.5 & $332 \cdot 4$ & 1.8 & 127 & \\
\hline 7 & 40 & 1014 & - & - & 1.8 & 314 & \\
\hline 8 & 44 & 1018 & $37 \cdot 5$ & $721 \cdot 8$ & $1 \cdot 7$ & 327 & \\
\hline 9 & 36 & 1018 & $47 \cdot 5$ & $748 \cdot 1$ & 1.8 & 283 & \\
\hline 10 & 36 & 1018 & - & - & $2 \cdot 3$ & 262 & \\
\hline 11 & 36 & 1018 & 52.5 & $826 \cdot 8$ & $2 \cdot 0$ & 315 & \\
\hline 14 & 68 & 1012 & - & - & 1.4 & 416 & \\
\hline 15 & 28 & 1006 & 40.0 & $490 \cdot 0$ & $2 \cdot 0$ & 245 & \\
\hline 16 & 26 & 1018 & $47 \cdot 5$ & 540.3 & $2 \cdot 2$ & 250 & \\
\hline 17 & 28 & 1018 & $37 \cdot 5$ & $459 \cdot 3$ & 1.9 & 232 & \\
\hline 18 & 32 & 1012 & - & - & 1.8 & 251 & \\
\hline
\end{tabular}

SUMMary OF QUANTITY OF URINE Passed.

Total qunntity. Daily average.

\begin{tabular}{|c|c|c|c|c|c|c|c|}
\hline \multicolumn{3}{|c|}{9 days of farinaceous diet } & . & - & 674 & $\ldots$ & 75 \\
\hline 16 & ", & full diet & - & - & 918 & ... & 57 \\
\hline 8 & ", & farinaceous diet & - & • & 320 & • & 40 \\
\hline 12 & " & ", & fish, and 2 & eggs & 608 & ט & 50 \\
\hline 33 & ", & ," & fish, 2 eggs & , and chop & 1356 & $\ldots$ & 41 \\
\hline
\end{tabular}

\section{SUMmary of Sprcipic Gravity.}

6 days of farinaceous diet $\quad . \quad$. $\quad . \quad . \quad . \quad 1010$

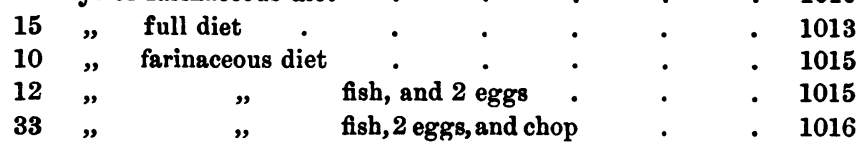

\section{SUMMARY OF QUANTITY OF ALBUMEN PASBEy.}

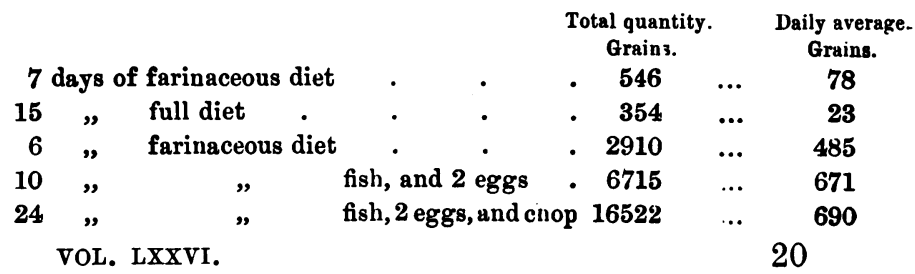




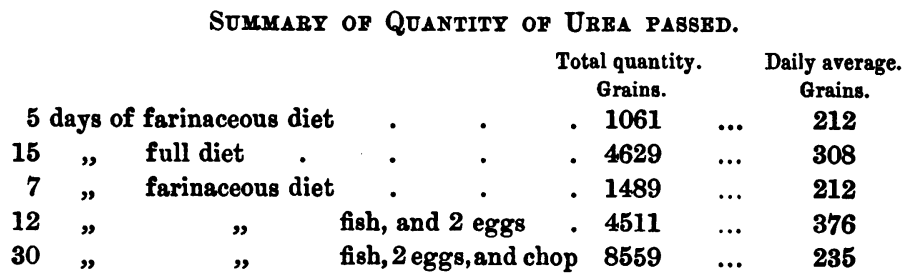

N.B.-As the patient was out of the hospital for five weeks between the full diet and the second farinaceous, they should not be contrasted.

CASE 2.-Chronic interstitial nephritis ; fatal.-Thomas M-, æt. 44, admitted into Guy's Hospital October 15th, 1890.

He has had gout for the last four or five years. He was in the Greenwich Hospital three months ago with swelling of the face, legs, and genitals. He has at times had fits. He has passed blood in his urine.

On admission.-There are tophi in his ears, and his hands, wrists, and knees are deformed by gout. His face is odematous. .The position of the apex of the heart is normal ; the first sound is rough, the second is accentuated; the pulse is hard, 94. The abdomen contains a little fluid; the eyes are normal.

October 20th.-Has had vomiting and diarrhœe the last few days ; a systolic murmur has been audible at the apex. Has been treated with compound jalap powder and subcutaneous injections of nitrate of pilocarpine.

Up to November 10th he had milk diet, jalap, and pilocarpine as required, and perchloride of iron thrice a day ; from this date he was put upon colchicum and full diet. He was able to get up on November 14th, and began to steadily improve in all respects, so that by December 6 th there was marked improvement, and he felt much stronger. About this time symptoms of cardiac failure again began to show themselves, and the patient gradually sank, and died on December 24th.

Post-mortem.-The aortic valves were thickened and everted, the mitral valve was thick. The heart was 
hypertrophied. The kidneys only weighed $5 \frac{1}{2}$ oz. They showed typical interstitial nephritis with much tubal change.

\begin{tabular}{|c|c|c|c|c|c|c|c|}
\hline \multirow[b]{2}{*}{ Date. } & \multirow{2}{*}{$\begin{array}{l}\text { No. of } \\
\text { oz in } \\
24 \mathrm{hrs} \text {. }\end{array}$} & \multirow[b]{2}{*}{ Sp. gr. } & \multicolumn{2}{|c|}{ ALBUMer. } & \multicolumn{2}{|c|}{ UREA. } & \multirow[b]{2}{*}{ Diet. } \\
\hline & & & $\begin{array}{l}\text { Parts } \\
\text { per } \\
1000 .\end{array}$ & $\begin{array}{l}\text { Total } \\
\text { grs. in } \\
24 \mathrm{hrs} .\end{array}$ & $\begin{array}{c}\text { Parts } \\
\text { per } \\
100 .\end{array}$ & $\begin{array}{l}\text { Total } \\
\text { grs. in } \\
24 \mathrm{hrs} .\end{array}$ & \\
\hline Oct. & & & & & & & \\
\hline 17 & 48 & 1010 & $1 \cdot 0$ & $21 \cdot 0$ & $1 \cdot 0$ & 230 & Milk. \\
\hline 20 & 48 & 1008 & 0.5 & $10 \cdot 4$ & $1 \cdot 0$ & 230 & \\
\hline 21 & 44 & 1010 & 0.5 & $9 \cdot 6$ & $1 \cdot 6$ & 337 & \\
\hline 22 & 16 & 1010 & 0.5 & 3.5 & $1 \cdot 2$ & 92 & \\
\hline 23 & 38 & 1010 & 0.5 & $8 \cdot 3$ & 1.0 & 182 & \\
\hline 24 & 40 & 1010 & 0.25 & $4 \cdot 3$ & $1 \cdot 0$ & 192 & \\
\hline 25 & 36 & 1010 & 0.5 & $7 \cdot 8$ & $1 \cdot 4$ & 241 & \\
\hline 26 & 36 & 1010 & 0.5 & $7 \cdot 8$ & - & - & \\
\hline 27 & 38 & 1010 & 0.5 & $8 \cdot 3$ & $1 \cdot 1$ & 201 & \\
\hline 28 & 36 & 1010 & $0 \cdot 4$ & $6 \cdot 3$ & $1 \cdot 0$ & 172 & \\
\hline 29 & 24 & 1010 & 0.5 & $5 \cdot 2$ & $1 \cdot 4$ & 161 & \\
\hline 30 & 26 & 1010 & 0.5 & $5 \cdot 6$ & $1 \cdot 2$ & 149 & \\
\hline \multirow{2}{*}{\multicolumn{8}{|c|}{ Nov. }} \\
\hline & & & & & & & \\
\hline 1 & 42 & 1010 & 0.5 & $9 \cdot 1$ & $1 \cdot 35$ & 272 & \\
\hline 2 & 40 & 1010 & - & - & - & - & \\
\hline 3 & 32 & 1010 & 0.5 & $7 \cdot 0$ & $1 \cdot 1$ & 168 & \\
\hline 4 & 32 & 1010 & 0.5 & 7.0 & 1.0 & 153 & \\
\hline 5 & 36 & 1010 & 0.5 & $7 \cdot 8$ & $1 \cdot 0$ & 172 & \\
\hline 6 & 40 & 1010 & 0.5 & $8 \cdot 7$ & $1 \cdot 0$ & 192 & \\
\hline 7 & 46 & 1010 & 0.5 & $10 \cdot 0$ & 0.9 & 198 & \\
\hline 8 & 68 & 1010 & 0.5 & $14 \cdot 9$ & 0.9 & 293 & \\
\hline 9 & 98 & 1010 & 0.5 & 26.4 & - & - & \\
\hline 10 & 70 & 1010 & 0.5 & $15 \cdot 3$ & $1 \cdot 15$ & 386 & \\
\hline 11 & 52 & 1008 & 0.3 & $6 \cdot 8$ & 0.9 & 224 & \\
\hline 12 & 60 & 1010 & 0.3 & $7 \cdot 8$ & 0.9 & 259 & Full diet, with one \\
\hline 13 & 42 & 1010 & 0.5 & $9 \cdot 1$ & $1 \cdot 1$ & 221 & chop, and sometimes \\
\hline 14 & 50 & 1010 & 0.5 & $10 \cdot 9$ & 0.9 & 216 & eggs. \\
\hline 15 & 36 & 1010 & 0.5 & $7 \cdot 8$ & $1 \cdot 4$ & 241 & \\
\hline 16 & 52 & - & - & - & - & - & \\
\hline 17 & 20 & 1010 & 0.5 & $4 \cdot 3$ & 0.9 & 86 & \\
\hline 18 & 50 & 1010 & 0.5 & $10 \cdot 9$ & $1 \cdot 2$ & 288 & \\
\hline 19 & 48 & 1010 & 0.5 & $10 \cdot 4$ & $0 . \overline{8}$ & 184 & \\
\hline 20 & 32 & 1010 & 0.5 & $7 \cdot 0$ & $0 \cdot 9$ & 138 & \\
\hline 21 & 40 & 1010 & 0.5 & $8 \cdot 7$ & 0.9 & 172 & \\
\hline 22 & 28 & 1010 & $0 \cdot 5$ & $5 \cdot 1$ & 0.8 & 107 & \\
\hline 23 & $\mathbf{3 4}$ & 1010 & 0.5 & $7 \cdot 4$ & 0.9 & 146 & \\
\hline 24 & 38 & 1010 & 0.5 & $8 \cdot \overline{3}$ & 0.9 & 164 & \\
\hline 25 & 40 & 1010 & $0 \cdot 6$ & $10 \cdot 5$ & 0.8 & 153 & \\
\hline 26 & 38 & 1010 & 0.6 & $8 \cdot 3$ & 0.9 & 164 & \\
\hline 27 & 36 & 1010 & 0.5 & $7 \cdot 8$ & 0.8 & 138 & \\
\hline 28 & 50 & 1010 & 0.5 & $10 \cdot 9$ & 0.9 & 216 & \\
\hline 29 & 36 & 1010 & 0.5 & $7 \cdot 8$ & $1 \cdot 4$ & 241 & \\
\hline 30 & 36 & 1010 & 0.5 & $7 \cdot 8$ & 0.8 & 138 & \\
\hline
\end{tabular}




\begin{tabular}{|c|c|c|c|c|c|c|c|}
\hline \multirow[b]{2}{*}{ Date. } & \multirow[b]{2}{*}{$\begin{array}{l}\text { No. of } \\
\text { oz. in } \\
24 \text { hrs }\end{array}$} & \multirow[b]{2}{*}{ Sp. gr. } & \multicolumn{2}{|c|}{ ALBUMRE. } & \multicolumn{2}{|c|}{ UREA. } & \multirow[b]{2}{*}{ Diet. } \\
\hline & & & $\begin{array}{c}\text { Parts } \\
\text { per } \\
1000 .\end{array}$ & $\begin{array}{c}\text { Total } \\
\text { xrs in } \\
24 \text { hrs. }\end{array}$ & $\begin{array}{c}\text { Parts } \\
\text { per } \\
100 .\end{array}$ & $\begin{array}{l}\text { Total } \\
\text { grs. in } \\
24 \text { irs. }\end{array}$ & \\
\hline $\begin{array}{c}\text { Dec. } \\
1 \\
2 \\
3 \\
4 \\
5 \\
6 \\
7 \\
7 \\
8 \\
9 \\
10 \\
11 \\
12 \\
13 \\
14 \\
15 \\
16 \\
17 \\
18 \\
19 \\
20 \\
21 \\
22 \\
23\end{array}$ & $\begin{array}{l}20 \\
38 \\
36 \\
36 \\
38 \\
24 \\
32 \\
36 \\
40 \\
38 \\
30 \\
38 \\
54 \\
36 \\
32 \\
34 \\
42 \\
44 \\
38 \\
32 \\
34 \\
32 \\
34\end{array}$ & $\begin{array}{l}1010 \\
1010 \\
1010 \\
1010 \\
1010 \\
1010 \\
1010 \\
1010 \\
1010 \\
1010 \\
1010 \\
1010 \\
1010 \\
-0 \\
1009 \\
1009 \\
1010 \\
1005 \\
1008 \\
1010 \\
1010 \\
1009 \\
1010\end{array}$ & $\begin{array}{l}0.5 \\
0.75 \\
0.5 \\
1.0 \\
1.0 \\
1.0 \\
-1.0 \\
1.0 \\
1.0 \\
1.0 \\
1.0 \\
1.0 \\
-1.5 \\
0.5 \\
0.4 \\
-5.5 \\
- \\
0.4 \\
0.5 \\
-\end{array}$ & \begin{tabular}{r|}
4.3 \\
$12 \cdot 4$ \\
$7 \cdot 8$ \\
$15 \cdot 7$ \\
$16 \cdot 6$ \\
$10 \cdot 5$ \\
- \\
$15 \cdot 7$ \\
$8 \cdot 6$ \\
$16 \cdot 6$ \\
$13 \cdot 1$ \\
$16 \cdot 6$ \\
$23 \cdot 6$ \\
-1. \\
$21 \cdot 0$ \\
$7 \cdot 4$ \\
$7 \cdot 3$ \\
$8 \cdot 3$ \\
5.9 \\
$7 \cdot 0$ \\
-
\end{tabular} & $\begin{array}{l}0.7 \\
0.9 \\
0.9 \\
0.8 \\
1.0 \\
0.9 \\
-9.9 \\
0.9 \\
1.0 \\
0.8 \\
0.9 \\
0.9 \\
0.9 \\
-.9 \\
0.9 \\
0.9 \\
0.9 \\
0.9 \\
0.9 \\
0.9 \\
0.9 \\
0.9 \\
1.0\end{array}$ & $\begin{array}{r}67 \\
164 \\
155 \\
138 \\
182 \\
103 \\
155 \\
192 \\
145 \\
129 \\
164 \\
227 \\
138 \\
161 \\
181 \\
190 \\
164 \\
138 \\
146 \\
138 \\
163\end{array}$ & $\begin{array}{l}\text { Chop discontinued, } \\
\text { otherwise the same. } \\
\text { Full diet, with chop. }\end{array}$ \\
\hline
\end{tabular}

Summary of Quantity of Urine Passed. Total quantity.
Ounces.

24 days of milk diet
Daily average. Ounces.

38 " full diet, chop, and sometimes egg . 1424 $\quad \ldots \quad$. 37

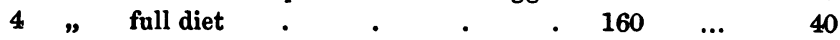

\section{SUMmary of Sphcific Gravity.}

24. days of milk diet

Daily average.

38 " full diet, chop, and sometimes egg . . . . 1009.7

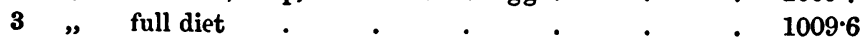

SUMmary OF QUANTity OF ALbUMen Passed.

Total quantity. Daily averaye.

Grains.

Grains.

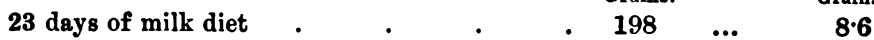

33 " full diet, chop, and sometimes egg . $297 \quad \ldots \quad$ 9.0

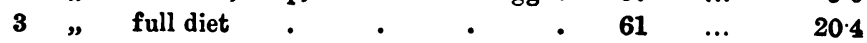




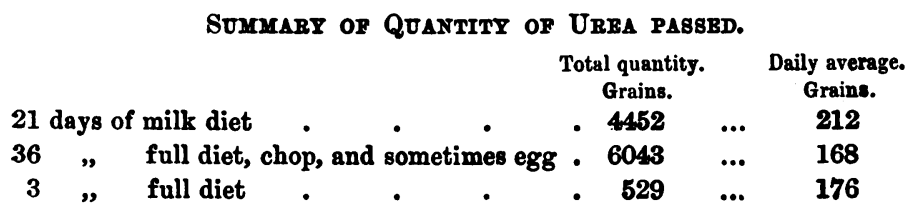

CasE 3. Chronic interstitial nephritis; fatal.-Samuel G-, æt. 38, admitted into Guy's Hospital April 8th, 1892. He is a painter. Clinical clerk, Mr. F. G. M. Phelps.

About last Christmas he began to suffer from cough and shortness of breath. This has got worse, and at the same time his feet and genitals have become odematous. He has to get up at night to pass his water.

On admission.-Is very anæmic ; there is much œdema and ascites. The apex-beat is in the nipple line, and the pulse is very hard and tension high. There is impaired resonance at the bases of both lungs, and there are a few moist râles in the chest. Albuminuric retinitis is present.

During his life the bronchitis troubled him much. Considerable fluid collected in his chest, which was aspirated. Southey's tubes were put in the legs. He suffered much from dyspncea, and towards the end he was drowsy.

Vapour-baths, pilocarpine, and jalap powder were all employed. Although in spite of treatment these organic symptoms progressed, there is a note on April 28th to say "Patient has certainly felt better since the milk diet was changed." He died May 13th.

Post-mortem.-There was well-marked chronic interstitial nephritis and some pneumonia in the lungs. 


\begin{tabular}{|c|c|c|c|c|c|c|c|}
\hline \multirow[b]{2}{*}{ Date. } & \multirow{2}{*}{$\begin{array}{l}\text { No. of } \\
\text { oz. in } \\
24 \mathrm{hrs} \text {. }\end{array}$} & \multirow[b]{2}{*}{ Sp. gr. } & \multicolumn{2}{|c|}{ ALBUMYN. } & \multicolumn{2}{|c|}{ UREA. } & \multirow[b]{2}{*}{ Diet. } \\
\hline & & & $\begin{array}{c}\text { Parts } \\
\text { per } \\
1000 .\end{array}$ & $\begin{array}{l}\text { Total } \\
\text { grs. in } \\
24 \mathrm{hrs} .\end{array}$ & $\begin{array}{c}\text { Parts } \\
\text { per } \\
100 .\end{array}$ & $\begin{array}{l}\text { Total } \\
\text { grs. in } \\
24 \text { hrs. }\end{array}$ & \\
\hline April & & & & & & & \\
\hline 11 & 28 & 1010 & $1 \cdot 0$ & $12 \cdot 2$ & - & - & Milk. \\
\hline 12 & 60 & 1010 & 0.75 & $20 \cdot 0$ & - & 367 & \\
\hline 13 & 64 & 1010 & 1.5 & $42 \cdot 0$ & - & 364 & \\
\hline 14 & 58 & 1008 & 1.0 & $25 \cdot 0$ & - & 336 & \\
\hline 15 & 60 & 1010 & $1 \cdot 0$ & $26 \cdot 0$ & - & - & \\
\hline 16 & 60 & 1008 & 0.75 & $21 \cdot 0$ & - & 341 & \\
\hline 18 & 48 & 1008 & $1 \cdot 2$ & $25 \cdot 0$ & - & - & Farinaceous. \\
\hline 19 & 40 & 1010 & $1 \cdot 4$ & 24.5 & - & 336 & \\
\hline 20 & - & - & - & - & - & 245 & \\
\hline 21 & 20 & 1012 & 1.25 & $10 \cdot 0$ & 一 & - & \\
\hline 22 & 32 & 1010 & $1 \cdot 25$ & $17 \cdot 5$ & - & 252 & \\
\hline 23 & 28 & 1012 & $1 \cdot 0$ & $12 \cdot 2$ & - & 232 & \\
\hline 25 & 38 & 1012 & $1 \cdot 0$ & $16 \cdot 6$ & - & 299 & $\begin{array}{l}\text { Farinaceous with fish } \\
\text { and arrowroot. }\end{array}$ \\
\hline 26 & 36 & 1012 & $1 \cdot 25$ & $19 \cdot 6$ & - & 283 & Farinaceous with \\
\hline 27 & - & 1012 & 1.5 & - & - & - & \\
\hline 28 & 28 & 1013 & $2 \cdot 0$ & $24 \cdot 5$ & - & 245 & \\
\hline 29 & 36 & 1012 & $1 \cdot 75$ & $27 \cdot 5$ & - & 299 & \\
\hline 30 & 40 & 1012 & - & - & 一 & 332 & \\
\hline May & & & & & & & \\
\hline 2 & 48 & 1012 & $1 \cdot 5$ & $31 \cdot 5$ & 一 & 399 & Farinaceous with fish \\
\hline 3 & 48 & 1012 & $1 \cdot 5$ & $31 \cdot 5$ & - & 378 & \\
\hline 4 & 36 & 1012 & $\begin{array}{l}1.0 \\
1.75\end{array}$ & $27 \cdot 5$ & - & 315 & \\
\hline 5 & 34 & 1010 & $2 \cdot 0$ & $29 \cdot 7$ & - & 282 & \\
\hline 6 & 55 & 1012 & $2 \cdot 0$ & $48 \cdot 1$ & - & 481 & \\
\hline 7 & 36 & 1012 & $2 \cdot 0$ & $31 \cdot 5$ & - & - & \\
\hline$\cdot 9$ & 20 & 1013 & $1 \cdot 75$ & $15 \cdot 3$ & - & 183 & \\
\hline 10 & 24 & 1013 & $1 \cdot 75$ & $18 \cdot 3$ & - & 220 & \\
\hline 11 & 34 & 1013 & 1.5 & $22 \cdot 3$ & - & 297 & \\
\hline 12 & 12 & 1012 & $1 \cdot 5$ & $7 \cdot 8$ & - & 105 & \\
\hline 13 & 20 & 1012 & $1 \cdot 25$ & $10 \cdot 9$ & 一 & 175 & \\
\hline
\end{tabular}

SUMmary of QUantity OF URINe PaSsed.

\begin{tabular}{|c|c|c|c|c|c|}
\hline \multirow{2}{*}{\multicolumn{2}{|c|}{6 days of milk diet }} & & \multicolumn{2}{|c|}{$\begin{array}{c}\text { Total quantity. } \\
\text { Ounces. }\end{array}$} & \multirow{2}{*}{$\begin{array}{l}\text { Daily average. } \\
\text { Ounces. } \\
55\end{array}$} \\
\hline & & . & . $\quad 330$ & $\ldots$ & \\
\hline 5 & farinaceous diet & . & 168 & $\ldots$ & 33 \\
\hline 4 & ", & and chicken & 140 & $\cdots$ & 35 \\
\hline 11 & $"$ & chicken, and fish & 367 & $\ldots$ & 33 \\
\hline
\end{tabular}




\section{Summáp of Sprotpic Gravity.}

\begin{tabular}{|c|c|c|c|c|c|}
\hline \multirow{2}{*}{\multicolumn{2}{|c|}{6 days of }} & \multicolumn{3}{|c|}{ SUMMARY OF SpRCIPIC Gravity. } & Daily average. \\
\hline & & milk diet & . & . & . $1009 \cdot 3$ \\
\hline 5 & ” & farinaceous diet & - & . & . 1010.4 \\
\hline 5 & ” & ” & and chicken & . & . $\quad 1012 \cdot 2$ \\
\hline 1 & ” & ” & chicken, and fish & . & . $\quad 1012 \cdot 1$ \\
\hline
\end{tabular}

SUMMary OF QUANTITY OF ALBUMRN PABgrd.

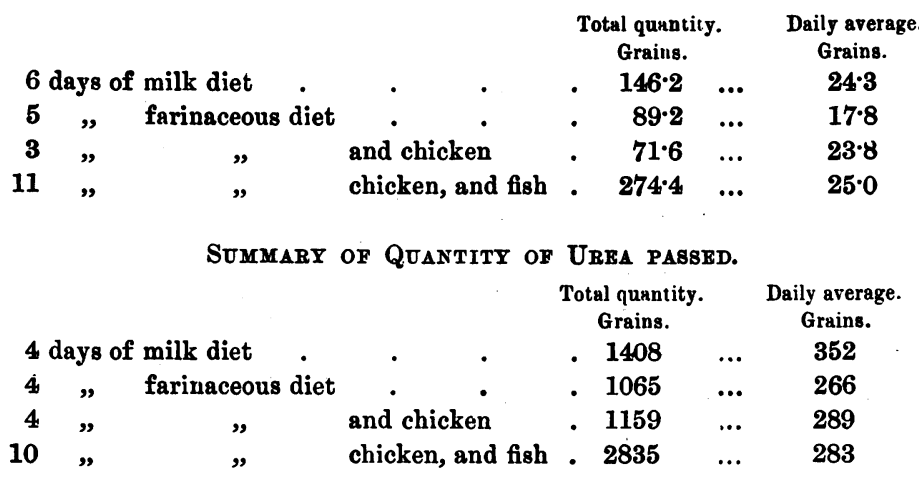

CASE 4. Chronic interstitial nephritis; fatal.-Thomas H-, æt. 47, admitted into Guy's Hospital 15th March, 1892. He has often had gout. Clinical clerk, Mr. G. A. Skinner.

On admission.-There is œdema of the eyelids. The cardiac dulness is increased, and the apex is outside the nipple. The pulse is high tension. There is a systolic bruit audible at the apex. There are retinal hæmorrhages and albuminuric retinitis. The patient never improved much; he suffered considerably from headache and dyspnœa. The retinitis progressed rapidly. The only time he improved was from May 7 th to May 16th, when he felt a little better, and was able to be up ; but as the œdema reappeared, he had to go back to bed. On May 21st; $32 \mathrm{oz}$. of clear fluid were withdrawn from each chest, and this was done again a week later. On May 28th he became maniacal and sank, and died on June 3rd. Various diuretics and diaphoretics were tried, but none of them did any good. 
Post-mortem.-There was found chronic interstitial nephritis, an hypertrophied heart, and gummata in the liver.

\begin{tabular}{|c|c|c|c|c|c|c|c|}
\hline \multirow[b]{2}{*}{ Date. } & \multirow{2}{*}{$\begin{array}{l}\text { No. of } \\
\text { oz. in } \\
24 \mathrm{hrs} \text {. }\end{array}$} & \multirow[b]{2}{*}{ Sp. gr. } & \multicolumn{2}{|c|}{ ALEUMRN. } & \multicolumn{2}{|c|}{ UnEA. } & \multirow[b]{2}{*}{ Diet. } \\
\hline & & & $\begin{array}{c}\text { Puris } \\
\text { per } \\
1000 .\end{array}$ & $\begin{array}{c}\text { Total } \\
\text { grs. in } \\
24 \text { hrs. }\end{array}$ & $\begin{array}{c}\text { Purts } \\
\text { per } \\
100 .\end{array}$ & $\begin{array}{l}\text { Total } \\
\text { grs. in } \\
24 \text { hrs. }\end{array}$ & \\
\hline March & & & & & & & \\
\hline 17 & 44 & 1010 & - & 17 & - & - & Fish. \\
\hline 18 & 44 & 1014 & - & 17 & - & - & \\
\hline 19 & 44 & 1015 & - & 17 & - & 一 & \\
\hline 20 & 44 & 1015 & - & 17 & - & 一 & \\
\hline 21 & 40 & 1015 & - & 16 & - & $\overline{9 \infty}$ & \\
\hline $\begin{array}{l}22 \\
23\end{array}$ & $\begin{array}{l}40 \\
30\end{array}$ & $\begin{array}{l}1012 \\
1014\end{array}$ & $\overline{-}$ & 40 & $1 \cdot 5$ & $\begin{array}{l}262 \\
157\end{array}$ & Full. \\
\hline $\begin{array}{l}23 \\
24\end{array}$ & 48 & 1012 & $\overline{-}$ & $\begin{array}{l}27 \\
48\end{array}$ & $\begin{array}{l}1 \cdot 2 \\
1 \cdot 2\end{array}$ & $\begin{array}{l}157 \\
252\end{array}$ & \\
\hline 25 & 48 & 1012 & - & 96 & $\overline{1} \cdot \overline{2}$ & 252 & Farinaceous. \\
\hline 26 & 48 & 1014 & - & 48 & $1 \cdot 2$ & 252 & \\
\hline 27 & 32 & 1012 & - & 32 & $1 \cdot 2$ & 168 & \\
\hline 28 & 48 & 1012 & - & 48 & $1 \cdot 3$ & 273 & \\
\hline 29 & 50 & - & - & 50 & $1 \cdot 2$ & 262 & \\
\hline 30 & 56 & 1010 & - & 56 & $1 \cdot 2$ & 294 & \\
\hline 31 & 60 & 1010 & - & 60 & $1 \cdot 2$ & 315 & \\
\hline \multicolumn{8}{|l|}{ April } \\
\hline 1 & 48 & 1011 & - & 31 & $1 \cdot 4$ & 294 & \\
\hline $\mathbf{2}$ & 58 & 1010 & - & 32 & $1 \cdot 0$ & 253 & \\
\hline 3 & 72 & - & - & 36 & - & $\overline{10}$ & \\
\hline 4 & $\begin{array}{l}50 \\
28\end{array}$ & $\begin{array}{l}1010 \\
1012\end{array}$ & $\overline{-}$ & $\overline{12}$ & 0.9 & 196 & \\
\hline $\begin{array}{l}5 \\
6\end{array}$ & $\begin{array}{l}28 \\
44\end{array}$ & $\begin{array}{l}1012 \\
1010\end{array}$ & $\bar{z}$ & $\begin{array}{l}12 \\
33\end{array}$ & $\begin{array}{l}1 \cdot 7 \\
1 \cdot 2\end{array}$ & $\begin{array}{l}208 \\
231\end{array}$ & \\
\hline 7 & 25 & - & - & 12 & - & - & \\
\hline 8 & 40 & 1012 & - & 20 & $1 \cdot 3$ & 227 & \\
\hline 9 & 48 & 1010 & - & 24 & $1 \cdot 2$ & 252 & \\
\hline 11 & 48 & 1010 & 一 & 36 & $1 \cdot 3$ & 273 & Farinaceous and fish. \\
\hline 12 & 56 & 1010 & - & 36 & $1 \cdot 25$ & 306 & \\
\hline 13 & 56 & - & - & 36 & 1.0 & 245 & \\
\hline 14 & 50 & 1010 & - & 32 & $1 \cdot 2$ & 262 & \\
\hline 15 & 48 & 1011 & - & 46 & $1 \cdot 3$ & 273 & \\
\hline 16 & 48 & 1008 & - & 31 & $1 \cdot 5$ & 314 & \\
\hline 18 & 48 & 1009 & - & 46 & $1 \cdot 2$ & 252 & \\
\hline 19 & 36 & 1014 & - & 40 & $1 \cdot 4$ & 220 & Farinaceous and \\
\hline 20 & 32 & 1014 & - & 41 & 1.5 & 219 & chicken. \\
\hline 21 & 20 & 1014 & - & 32 & $1 \cdot 8$ & 137 & \\
\hline 22 & 24 & 1012 & - & 42 & $1 \cdot 8$ & 188 & Farinaceous. \\
\hline 23 & 24 & 1010 & - & - & $1 \cdot 9$ & 199 & \\
\hline 25 & 28 & 1014 & - & 67 & 1.8 & 220 & \\
\hline 26 & 28 & 1012 & - & 70 & $1 \cdot 9$ & 232 & \\
\hline 27 & 28 & 1014 & 一 & 57 & $\overline{-1}$ & $\overline{0 \Omega}$ & \\
\hline $\begin{array}{l}28 \\
29\end{array}$ & $\begin{array}{l}32 \\
36\end{array}$ & $\begin{array}{l}1012 \\
1012\end{array}$ & $\bar{z}$ & $\begin{array}{l}64 \\
86\end{array}$ & 1.7 & 238 & Cocos \\
\hline 30 & 36 & 1012 & - & 65 & $1 \cdot 4$ & 220 & \\
\hline
\end{tabular}


VARIOUS DIETS IN BRIGHT'S DISEASE.

\begin{tabular}{|c|c|c|c|c|c|c|c|}
\hline \multirow[b]{2}{*}{ Dute. } & \multirow{2}{*}{$\begin{array}{l}\text { No. of } \\
\text { ox in } \\
24 \text { hrs. }\end{array}$} & \multirow[b]{2}{*}{ Sp. gr. } & \multicolumn{2}{|c|}{ ALBUYEN. } & \multicolumn{2}{|c|}{ UREA. } & \multirow[b]{2}{*}{ Diet. } \\
\hline & & & $\begin{array}{c}\text { Parts } \\
\text { per } \\
1000 .\end{array}$ & $\begin{array}{l}\text { Total } \\
\text { grs. in } \\
24 \text { hrs. }\end{array}$ & $\begin{array}{l}\text { Parts } \\
\text { per } \\
100 .\end{array}$ & $\begin{array}{l}\text { Total } \\
\text { grs. in } \\
24 \text { hrs. }\end{array}$ & \\
\hline $\begin{array}{c}\text { May } \\
2 \\
3 \\
4 \\
5 \\
6 \\
7 \\
8 \\
9 \\
10 \\
11 \\
12 \\
13 \\
14 \\
15 \\
16 \\
17 \\
18 \\
19 \\
20 \\
21 \\
22 \\
23 \\
24 \\
25 \\
27\end{array}$ & $\begin{array}{r}41 \\
12 \\
12 \\
20 \\
20 \\
32 \\
24 \\
20 \\
24 \\
28 \\
28 \\
20 \\
8 \\
24 \\
16 \\
20 \\
20 \\
16 \\
16 \\
24 \\
28 \\
20 \\
20 \\
24 \\
16\end{array}$ & $\begin{array}{c}1010 \\
1012 \\
1016 \\
1014 \\
1015 \\
1015 \\
\overline{1010} \\
1010 \\
1012 \\
1012 \\
1012 \\
1012 \\
\overline{1012} \\
\overline{1012} \\
1014 \\
1012 \\
1014 \\
\overline{1012} \\
1012 \\
1012 \\
1012\end{array}$ & $\begin{array}{l}\bar{z} \\
\bar{z} \\
\bar{z} \\
\bar{z} \\
\bar{z} \\
\bar{z} \\
\bar{z} \\
\bar{z} \\
\bar{z} \\
\bar{z} \\
\bar{z}\end{array}$ & $\begin{array}{l}90 \\
31 \\
40 \\
48 \\
- \\
= \\
\overline{31} \\
33 \\
36 \\
45 \\
18 \\
\frac{12}{12} \\
\overline{19} \\
14 \\
16 \\
18 \\
\overline{19} \\
17 \\
21 \\
16\end{array}$ & $\begin{array}{l}1.6 \\
1.5 \\
1.5 \\
1.3 \\
1.6 \\
= \\
1.7 \\
1.6 \\
1.5 \\
1.9 \\
1.6 \\
1.7 \\
11.5 \\
\frac{1}{1.7} \\
1.5 \\
1.6 \\
1.5 \\
1.5 \\
1.6 \\
1.6 \\
1.7\end{array}$ & $\begin{array}{r}287 \\
78 \\
78 \\
113 \\
140 \\
- \\
\overline{148} \\
168 \\
183 \\
232 \\
140 \\
59 \\
\overline{104} \\
\overline{148} \\
104 \\
112 \\
157 \\
\overline{131} \\
140 \\
168 \\
119\end{array}$ & Farinaceous and fish. \\
\hline
\end{tabular}

\section{SUMMARY OF QUANTITY OF URING PABSBD.}

\begin{tabular}{|c|c|c|c|c|c|c|c|}
\hline & & & & & $\begin{array}{l}\text { Total quant } \\
\text { Ounces. }\end{array}$ & & $\begin{array}{c}\text { Daily average. } \\
\text { Ounces. }\end{array}$ \\
\hline & ys & farinaceous and & fish diet & • & . 216 & ... & 43 \\
\hline $\mathbf{3}$ & $"$ & full diet & - & - & 118 & ... & 39 \\
\hline 16 & " & farinaceous diet & - & - & 755 & ... & 47 \\
\hline 7 & , & " & and fish & - & 354 & $\ldots$ & 50 \\
\hline 3 & 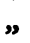 & $\eta$ & and chicke & & 88 & ... & 29 \\
\hline 6 & 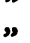 & 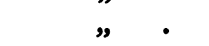 & - & 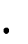 & . 164 & ... & 27 \\
\hline 11 & ” & ø & and cocoa & . & . $\quad 287$ & ... & 26 \\
\hline 5 & 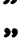 & full diet & . & - & . 108 & $\ldots$ & 21 \\
\hline 11 & " & farinaceous diet & and fish & & . 220 & $\ldots$ & 20 \\
\hline
\end{tabular}




\section{Summary of Speoific Gravity.}

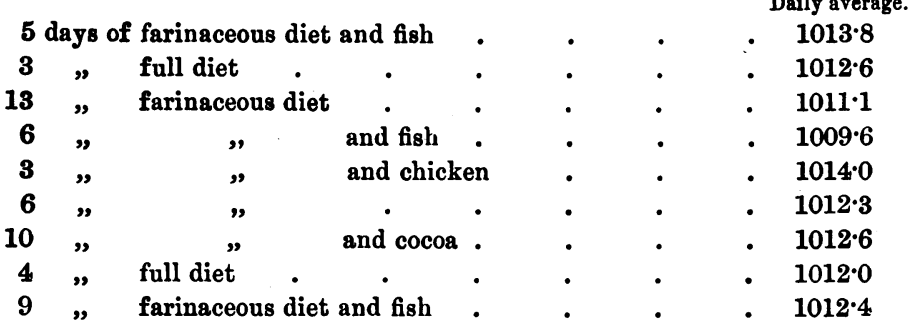

SUMMaRY OF QUANTITY OF ALbUMEN PABSED.

\begin{tabular}{|c|c|c|c|c|c|c|}
\hline \multirow{2}{*}{\multicolumn{2}{|c|}{5 days }} & & & \multicolumn{2}{|c|}{$\begin{array}{l}\text { Total quantity. } \\
\text { Grains. }\end{array}$} & \multirow{2}{*}{$\begin{array}{c}\text { Daily average } \\
\text { Grains. } \\
16 \cdot 8\end{array}$} \\
\hline & & farinaceous diet & and fish & 84 & $\cdots$ & \\
\hline 3 & " & full diet & • & - $\quad 115$ & $\ldots$ & $38 \cdot 3$ \\
\hline 15 & $\eta$ & farinaceous diet & . & 590 & $\ldots$ & $39 \cdot 3$ \\
\hline 7 & ", & " & and fish & 263 & ... & $37 \cdot 5$ \\
\hline $\mathbf{3}$ & " & ” & and chicken & - 113 & ... & $37 \cdot 6$ \\
\hline 5 & ", & ” & - & . 300 & ... & $60 \cdot 0$ \\
\hline 7 & ” & ” & and cocoa . & 391 & $\cdots$ & $55 \cdot 8$ \\
\hline 4 & , & full diet & - & 132 & $\ldots$ & $33 \cdot 0$ \\
\hline 9 & ” & farinaceous diet & and fish & 152 & $\ldots$ & $16 \cdot 8$ \\
\hline
\end{tabular}

\begin{tabular}{|c|c|c|c|c|c|c|c|}
\hline & & SUMMARY & OF QUANTII & TY OF & $\begin{array}{r}\text { UREA P } \\
\text { Total quan } \\
\text { Grains }\end{array}$ & & $\begin{array}{c}\text { Daily average. } \\
\text { Grains. }\end{array}$ \\
\hline & ys of & full diet & . & . & 671 & $\ldots$ & 223 \\
\hline 14 & , & farinaceous diet & . & . & . 3477 & $\ldots$ & 248 \\
\hline 7 & 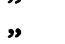 & , & and fish & . & . 1925 & $\ldots$ & 275 \\
\hline 3 & $"$ & , & and chicker & & . 576 & $\ldots$ & 192 \\
\hline 5 & , & " & . & . & . 1077 & $\ldots$ & 215 \\
\hline 8 & ", & ", & and cocoa & . & . 1232 & $\ldots$ & 154 \\
\hline 4 & ” & full diet & . & . & - 614 & $\ldots$ & 153 \\
\hline 9 & $"$ & farinaceous diet & and fish & . & . 1183 & $\ldots$ & 131 \\
\hline
\end{tabular}

CASE 5. Chronic interstitial nephritis.-George R-, æt. 63, admitted into Guy's Hospital May 22nd, 1892. Clinical clerk, Mr. A. L. Roper. The patient has had gout for thirty-three years. Lately he has noticed that his eyelids have been swollen.

On admission.-He has tophi in his ears. His chest is emphysematous. The pulse is hard; the apex-beat cannot be felt. 
From June 15th to June 20th, he had severe uræmia, as shown by convulsions, coma, and vomiting. He was treated with vapour-baths, elaterium, and pilocarpine. He gradually got better, and was able to get up on July 5th. Except that for a few days about July 9th he had headache he did well, and was able to leave the hospital on July 24th better in all respects than when he came in.

\begin{tabular}{|c|c|c|c|c|c|c|c|}
\hline \multirow[b]{2}{*}{ Date. } & \multirow{2}{*}{$\begin{array}{l}\text { No. of } \\
\text { oz. in } \\
24 \mathrm{hrs} .\end{array}$} & \multirow[b]{2}{*}{ Sp. gr. } & \multicolumn{2}{|c|}{ AldBumer. } & \multicolumn{2}{|c|}{ UrEA. } & \multirow[b]{2}{*}{ Diet. } \\
\hline & & & $\begin{array}{l}\text { Parts } \\
\text { per } \\
1000 .\end{array}$ & $\begin{array}{l}\text { Total } \\
\text { grs. in } \\
24 \text { hrs. }\end{array}$ & $\begin{array}{l}\text { Parts } \\
\text { per } \\
100 .\end{array}$ & $\begin{array}{l}\text { Total } \\
\text { grs. in } \\
24 \text { hrs. }\end{array}$ & \\
\hline May & & & & & & & \\
\hline 25 & 20 & 1010 & $1 \cdot 0$ & $8 \cdot 7$ & 1.5 & 130 & Farinaceous with \\
\hline 26 & 16 & 1012 & $1 \cdot 0$ & $7 \cdot 0$ & $1 \cdot 4$ & 98 & milk. \\
\hline 27 & 20 & 1012 & $7 \cdot 0$ & $61 \cdot 0$ & $1 \cdot 6$ & 140 & \\
\hline 28 & 20 & 1012 & $7 \cdot 0$ & $61 \cdot 0$ & $1 \cdot 6$ & 140 & \\
\hline 30 & 16 & 1016 & $20 \cdot 0$ & $140 \cdot 0$ & $1 \cdot 6$ & 112 & \\
\hline 31 & 28 & 1018 & $15 \cdot 0$ & $178 \cdot 0$ & $1 \cdot 8$ & 212 & \\
\hline \multicolumn{8}{|l|}{ June } \\
\hline 1 & 36 & 1016 & $12 \cdot 0$ & $189 \cdot 0$ & $2 \cdot 0$ & 317 & Farinaceous and fish. \\
\hline 2 & 32 & 1020 & $15 \cdot 0$ & $208 \cdot 0$ & $2 \cdot 0$ & 279 & \\
\hline 3 & 20 & 1020 & $13 \cdot 0$ & $113 \cdot 0$ & $2 \cdot 2$ & 192 & \\
\hline 10 & 28 & 1016 & $8 \cdot 0$ & $98 \cdot 0$ & $1 \cdot \mathbf{4}$ & 171 & Farinaceous. \\
\hline 11 & 48 & 1016 & $12 \cdot 0$ & $251 \cdot 0$ & $1 \cdot 6$ & 336 & \\
\hline 12 & 24 & 1015 & $10 \cdot 0$ & $104 \cdot 0$ & $1 \cdot 3$ & 135 & \\
\hline 13 & 32 & 1012 & $12 \cdot 0$ & $168 \cdot 0$ & $1 \cdot 2$ & 167 & \\
\hline 14 & 44 & 1016 & $12 \cdot 0$ & $231 \cdot 0$ & $1 \cdot 1$ & 211 & \\
\hline 15 & 40 & 1014 & $13 \cdot 5$ & $236 \cdot 0$ & $1 \cdot 2$ & 210 & \\
\hline 16 & - & 1016 & $18 \cdot 0$ & - & $1 \cdot 1$ & - & \\
\hline 17 & 20 & 1020 & $12 \cdot 0$ & $104 \cdot 0$ & $1 \cdot 4$ & 122 & \\
\hline 18 & 50 & 1020 & $6 \cdot 0$ & $130 \cdot 0$ & $1 \cdot 8$ & 393 & \\
\hline 20 & 36 & 1018 & $9 \cdot 0$ & $140 \cdot 0$ & $1 \cdot 8$ & 285 & \\
\hline 21 & 54 & 1018 & $7 \cdot 5$ & $172 \cdot 0$ & $2 \cdot 1$ & 496 & Full. \\
\hline 22 & 30 & 1016 & $6 \cdot 0$ & $78 \cdot 0$ & $1 \cdot 8$ & 236 & \\
\hline 23 & 50 & 1012 & $6 \cdot 0$ & $131 \cdot 0$ & $1 \cdot 8$ & 393 & \\
\hline 24 & 50 & 1012 & $10 \cdot 5$ & $225 \cdot 0$ & $1 \cdot 8$ & 393 & \\
\hline 25 & 48 & 1012 & $9 \cdot 0$ & $187 \cdot 0$ & - & - & \\
\hline 27 & 60 & 1010 & $3 \cdot 0$ & $78 \cdot 0$ & 1.7 & 446 & \\
\hline 28 & 50 & 1012 & 4.5 & $98 \cdot 0$ & $1 \cdot 3$ & 284 & \\
\hline 29 & 54 & 1014 & $3 \cdot 0$ & $70 \cdot 0$ & $1 \cdot 6$ & 378 & \\
\hline 30 & 54 & 1013 & - & - & $1 \cdot 6$ & 378 & \\
\hline \multicolumn{8}{|l|}{ July } \\
\hline 1 & 64 & 1014 & 1.5 & $41 \cdot 0$ & $1 \cdot 2$ & 336 & \\
\hline 2 & 36 & 1012 & 1.5 & $23 \cdot 0$ & $1 \cdot 4$ & 214 & \\
\hline 4 & 64 & 1014 & 1.5 & $41 \cdot 0$ & $1 \cdot 3$ & 373 & \\
\hline 5 & 40 & 1014 & $1 \cdot 5$ & $26 \cdot 0$ & $1 \cdot 4$ & 245 & \\
\hline 6 & 56 & 1014 & 1.5 & $36^{\circ} 0$ & $1 \cdot 3$ & 321 & \\
\hline 7 & 58 & 1010 & $2 \cdot 5$ & $61 \cdot 0$ & $1 \cdot 2$ & 304 & \\
\hline 8 & 52 & 1010 & $2 \cdot 5$ & $64 \cdot 0$ & $1 \cdot 1$ & 249 & \\
\hline O & 80 & 1008 & $2 \cdot 0$ & $70 \cdot 0$ & 0.8 & 216 & \\
\hline
\end{tabular}




\begin{tabular}{|c|c|c|c|c|c|c|c|}
\hline \multirow{2}{*}{ Date. } & \multirow{2}{*}{$\begin{array}{l}\text { No. of } \\
\text { oz. in } \\
24 \mathrm{hrs} \text {. }\end{array}$} & \multirow{2}{*}{ Sp. gr. } & \multicolumn{2}{|c|}{ ALBUMKN. } & \multicolumn{2}{|c|}{ URRA. } & \multirow{2}{*}{ Diet. } \\
\hline & & & $\begin{array}{c}\text { Parts } \\
\text { per } \\
1000 .\end{array}$ & $\begin{array}{l}\text { Total } \\
\text { grs. in } \\
24 \mathrm{hrs} .\end{array}$ & $\begin{array}{c}\text { Parts } \\
\text { per } \\
\mathbf{j 0 0 .}\end{array}$ & $\begin{array}{l}\text { Total } \\
\text { grs. in } \\
24 \text { hrs. }\end{array}$ & \\
\hline $\begin{array}{c}\text { July } \\
11 \\
12 \\
13 \\
14 \\
15 \\
16 \\
18 \\
19 \\
20 \\
21 \\
22\end{array}$ & $\begin{array}{l}64 \\
64 \\
64 \\
68 \\
64 \\
64 \\
45 \\
60 \\
60 \\
60 \\
48\end{array}$ & $\begin{array}{l}1010 \\
1012 \\
1008 \\
1010 \\
1010 \\
1010 \\
1010 \\
1012 \\
1010 \\
1010 \\
1008\end{array}$ & $\begin{array}{l}2 \cdot 0 \\
2 \cdot 0 \\
2 \cdot 0 \\
1 \cdot 5 \\
1 \cdot 5 \\
1 \cdot 0 \\
1 \cdot 0 \\
1 \cdot 0 \\
1 \cdot 0 \\
1 \cdot 0 \\
0 \cdot 5\end{array}$ & $\begin{array}{l}56 \cdot 0 \\
56 \cdot 0 \\
56 \cdot 0 \\
44 \cdot 0 \\
41 \cdot 0 \\
28 \cdot 0 \\
17 \cdot 0 \\
26 \cdot 0 \\
26 \cdot 0 \\
26 \cdot 0 \\
10 \cdot 0\end{array}$ & $\begin{array}{l}1 \cdot 1 \\
1 \cdot 0 \\
1 \cdot 2 \\
1 \cdot 1 \\
1 \cdot 1 \\
1 \cdot 1 \\
1 \cdot 2 \\
1 \cdot 1 \\
1 \cdot 2 \\
1 \cdot 2 \\
1 \cdot 0\end{array}$ & $\begin{array}{l}307 \\
279 \\
336 \\
328 \\
307 \\
307 \\
236 \\
288 \\
315 \\
315 \\
209\end{array}$ & Full. \\
\hline
\end{tabular}

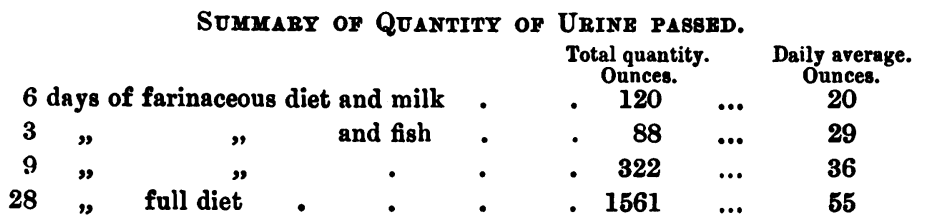

Sommary of Specific Gravity.

6 days of farinaceous diet and milk .

Daily average. $1013 \cdot 3$

30
and fish

$1018 \cdot 6$ ,

$"$

SOMMARY OF QUANTITY OF ALBUMEN PABSED.

days of farinaceous diet and milk

Total quantity. Daily average.
Grains.
Grains.
3 "
and fish
9 ,
- 510
... 170
27 "
full diet
- 1462
... 162
$\begin{array}{rrr}\text { - } 1787 \quad \ldots & 66\end{array}$

- $455 \cdot 7$

76

SUMMARY OF QUANTITY OF UREA PASGED.

6 days of farinaceous diet and milk

Total quantity. Daily average.
Grains.
Grains.

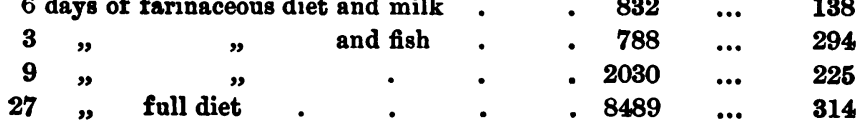

CasE 6. Chronic interstitial nephritis.-Matilda C-, æt. 71, admitted into Guy's Hospital 12th May, 1891. Clinical clerk, Mr. F. Wallace Wilson. 
She says she caught cold last winter. A few weeks ago the feet began to swell, and the eyelids to be puffy. Soon after the abdomen began to distend, and she suffered from dyspncea.

On admission.-There is subconjunctival œdema and puffiness beneath the eyes. The legs are codematous, and there is a well-marked lumbar cushion. The præcordial dulness is increased, and a distinct pericardial rub is audible. There is also a systolic endocardial murmur, best heard at the apex. The pulse is rapid, weak, and irregular. There is impaired resonance with râles at the bases of both lungs. She was ordered small doses of tincture of digitalis and acetate of ammonium, together with a mustard leaf over the pericardium. The pericardial rub slowly disappeared; the patient improved in all respects, and left the hospital on June 7th, 1891.

\begin{tabular}{|c|c|c|c|c|c|c|c|}
\hline \multirow[b]{2}{*}{ Date. } & \multirow{2}{*}{$\begin{array}{l}\text { No. of } \\
\text { oz. in } \\
24 \mathrm{hrs} .\end{array}$} & \multirow[b]{2}{*}{ Sp. gr. } & \multicolumn{2}{|c|}{ ALBUUMEN. } & \multicolumn{2}{|c|}{ UREA. } & \multirow[b]{2}{*}{ Diet. } \\
\hline & & & $\begin{array}{c}\text { Parts } \\
\text { per } \\
1000 .\end{array}$ & $\begin{array}{l}\text { Total } \\
\text { grs. in } \\
24 \text { hirs. }\end{array}$ & $\begin{array}{c}\text { Parts } \\
\text { per } \\
100 .\end{array}$ & $\begin{array}{l}\text { Total } \\
\text { gra. in } \\
24 \text { hrs. }\end{array}$ & \\
\hline $\begin{array}{c}\text { May } \\
14 \\
15 \\
16 \\
17 \\
18 \\
19 \\
20 \\
21 \\
22 \\
23 \\
24 \\
25 \\
26 \\
27 \\
28 \\
29 \\
30 \\
31 \\
\text { June } \\
1 \\
2 \\
3 \\
4 \\
5 \\
6\end{array}$ & $\begin{array}{r}24 \\
98 \\
142 \\
152 \\
156 \\
132 \\
76 \\
108 \\
96 \\
72 \\
52 \\
60 \\
80 \\
68 \\
60 \\
48 \\
70 \\
48\end{array}$ & $\begin{array}{c}1022 \\
1010 \\
1008 \\
1009 \\
1010 \\
- \\
1010 \\
1010 \\
- \\
1012 \\
- \\
1016 \\
1010 \\
1012 \\
1014 \\
1016 \\
1010 \\
- \\
1018 \\
1020 \\
1020 \\
1014 \\
1016 \\
1018\end{array}$ & $\begin{array}{c}\text { Trace } \\
\text { None } \\
\text { " } \\
" \\
" \\
" \\
" \\
" \\
" \\
" \\
" \\
" \\
" \\
"\end{array}$ & $\begin{array}{l}= \\
= \\
= \\
= \\
= \\
= \\
= \\
= \\
= \\
= \\
= \\
= \\
=\end{array}$ & $\begin{array}{l}\overline{0.8} \\
0.3 \\
0.45 \\
0.5 \\
-\overline{1.0} \\
0.9 \\
0.9 \\
1 \cdot 4 \\
- \\
2 \cdot 1 \\
1.3 \\
1.5 \\
2.1 \\
1.9 \\
1.5 \\
-\end{array}$ & $\begin{array}{r}-\overline{343} \\
186 \\
297 \\
340 \\
-\overline{338} \\
424 \\
393 \\
440 \\
- \\
550 \\
454 \\
446 \\
550 \\
398 \\
459 \\
- \\
454 \\
281 \\
363 \\
398 \\
503 \\
273\end{array}$ & $\begin{array}{l}\text { Milk. } \\
\text { Farinaceous. }\end{array}$ \\
\hline
\end{tabular}




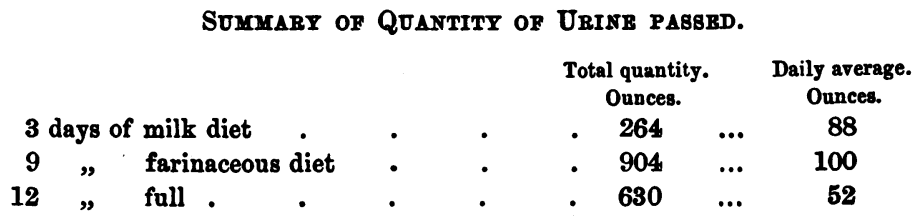

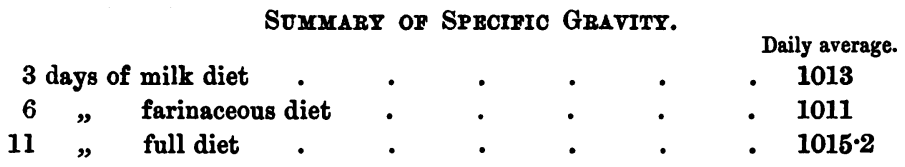

\section{ALBUMEN.}

After the first day there was none on any diet.

SUMMARY OF QUANTITY OF UREA PASSED.

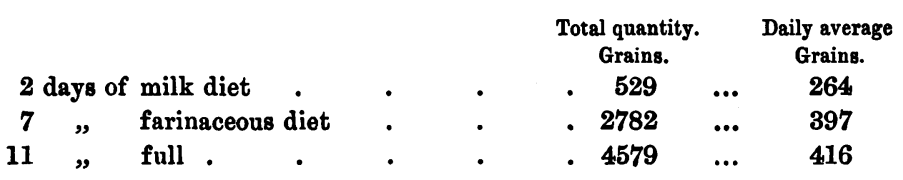

CASE 7. Chronic interstitial nephritis.-Thomas R-, æt. 67, admitted into Guy's Hospital 9th May, 1891.

Nine months ago his feet and ankles began to swell, he also had pain in the head, shortness of breath, and cough, and he suffered from indigestion, constipation, and epistaxis.

On admission.-There was much œdema of the feet. The apex of the heart could not be felt, but there was a faint systolic murmur audible in its usual position. The pulse was very hard and 66 to the minute. The breathing was harsh. He was ordered acetate of ammonium. He left the hospital on June 9th, and said he felt better than when he came in. 
VARIOUS DIETS IN BRIGHT'S DISEASE.

\begin{tabular}{|c|c|c|c|c|c|c|c|}
\hline \multirow[b]{2}{*}{ Date. } & \multirow{2}{*}{$\begin{array}{l}\text { No. of } \\
\text { oz. in } \\
24 \mathrm{hrs} .\end{array}$} & \multirow[b]{2}{*}{ Sp. gr. } & \multicolumn{2}{|c|}{ ALBUXBXY. } & \multicolumn{2}{|c|}{ Urka. } & \multirow[b]{2}{*}{ Diet. } \\
\hline & & & $\begin{array}{c}\text { Parts } \\
\text { per } \\
1000 .\end{array}$ & $\begin{array}{l}\text { Total } \\
\text { grs. in } \\
24 \mathrm{hrs} .\end{array}$ & $\begin{array}{c}\text { Parts } \\
\text { per } \\
100 .\end{array}$ & $\begin{array}{c}\text { Total } \\
\text { grs. in } \\
24 \text { brs. }\end{array}$ & \\
\hline $\begin{array}{c}\text { May } \\
10 \\
11 \\
12 \\
13 \\
14 \\
15 \\
16 \\
17 \\
18 \\
19 \\
20 \\
21 \\
22 \\
23 \\
25 \\
26 \\
27 \\
28 \\
29 \\
30 \\
31 \\
\\
\text { June } \\
1 \\
2 \\
3 \\
4 \\
5 \\
6\end{array}$ & $\begin{array}{l}\overline{32} \\
64 \\
48 \\
52 \\
52 \\
58 \\
46 \\
28 \\
34 \\
60 \\
40 \\
40 \\
20 \\
52 \\
34 \\
36 \\
36 \\
40 \\
44 \\
44\end{array}$ & $\begin{array}{c}1008 \\
\overline{1012} \\
- \\
1012 \\
1010 \\
1010 \\
- \\
1020 \\
- \\
1014 \\
1020 \\
1016 \\
1018 \\
1016 \\
1016 \\
1012 \\
1020 \\
1016 \\
1014 \\
-\end{array}$ & $\begin{array}{l}\bar{z} \\
\bar{z} \\
\bar{z} \\
\bar{z} \\
\bar{z} \\
\bar{z} \\
\bar{z} \\
\bar{z} \\
\bar{z}\end{array}$ & $\begin{array}{l}\bar{z} \\
\bar{z} \\
\bar{z} \\
\bar{z} \\
\bar{z} \\
\bar{z} \\
\bar{z} \\
\bar{z} \\
\bar{z} \\
\bar{z}\end{array}$ & $\begin{array}{l}\bar{Z} \\
\overline{1} \\
1.3 \\
1.8 \\
1.8 \\
1.7 \\
\overline{1.5} \\
\overline{2.3} \\
1.9 \\
2.0 \\
1.5 \\
1.5 \\
1.7 \\
2.0 \\
2.6 \\
2.4 \\
1.8 \\
-\end{array}$ & $\begin{array}{r}\bar{Z} \\
\bar{z} \\
273 \\
409 \\
409 \\
431 \\
\overline{183} \\
183 \\
603 \\
332 \\
350 \\
131 \\
341 \\
252 \\
315 \\
409 \\
420 \\
346 \\
-\end{array}$ & $\begin{array}{l}\text { Full with egg for } \\
\text { breakfast. }\end{array}$ \\
\hline
\end{tabular}

Blood and albumen present during the whole time, but they diminished towards the end.

SUMMary of QUANTITY OF URINE PASSED.

Total quantity. Daily average.

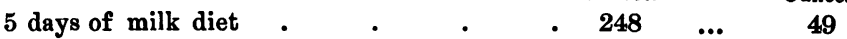

$\begin{array}{lllllllll}5 & & \text { full diet } \quad . & \text {. } & \text {. } & \text {. } & 378 & \ldots & 42\end{array}$

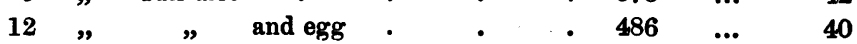

Stmmary of Spectfic Gratity.

4 days of milk diet

Daily average.

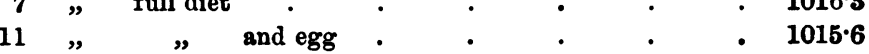




\section{SUMMARY OF QUANTITY OF UREA PASBgD.}

\begin{tabular}{|c|c|c|c|c|c|c|c|}
\hline \multirow{2}{*}{\multicolumn{2}{|c|}{3 days of milk diet }} & & & & $\begin{array}{l}\text { Total quantity. } \\
\text { Grains. }\end{array}$ & & $\begin{array}{l}\text { Daily average. } \\
\text { Grains. }\end{array}$ \\
\hline & & $t$ & - & - & . 1091 & ... & 363 \\
\hline 7 & full diet & . & . & $\cdot$ & . 2371 & ... & 338 \\
\hline 11 & ” & and egg & . & . & . 3792 & $\ldots$ & 344 \\
\hline
\end{tabular}

Case 8. Chronic interstitial nephritis.-Matilda $\mathrm{H}-$-, æt. 46, admitted into Guy's Hospital 11th March, 1891. Clinical clerk, Mr. F. H. Evans.

In this case there was no doubt about the diagnosis because she had well-marked albuminuric retinitis. The heart was hypertrophied. She did not stay in the hospital long, but went home at her own wish. She said she was quite sure that she felt much better on fish than on farinaceous diet.

\begin{tabular}{|c|c|c|c|c|c|c|c|}
\hline \multirow{2}{*}{ Date. } & \multirow{2}{*}{$\begin{array}{l}\text { No. of } \\
\text { oz. in } \\
24 \mathrm{hrs} \text {. }\end{array}$} & \multirow{2}{*}{ Sp. gr. } & \multicolumn{2}{|c|}{ ALBUMBN. } & \multicolumn{2}{|c|}{ UrRa. } & \multirow{2}{*}{ Diet. } \\
\hline & & & $\begin{array}{c}\text { Parts } \\
\text { per } \\
1000 .\end{array}$ & $\begin{array}{l}\text { Total } \\
\text { grs. in } \\
24 \text { hrs. }\end{array}$ & $\begin{array}{c}\text { Parts } \\
\text { per } \\
100 .\end{array}$ & $\begin{array}{l}\text { Total } \\
\text { grs. in } \\
24 \text { hrs. }\end{array}$ & \\
\hline $\begin{array}{c}\text { March } \\
11 \\
12 \\
13 \\
14 \\
16 \\
17 \\
18 \\
19 \\
20 \\
21 \\
23 \\
24 \\
25 \\
26 \\
28 \\
30 \\
\text { April } \\
1 \\
2\end{array}$ & $\begin{array}{l}- \\
\overline{48} \\
24 \\
24 \\
46 \\
48 \\
28 \\
24 \\
44 \\
20 \\
36 \\
36 \\
16 \\
46 \\
32\end{array}$ & $\begin{array}{l}1012 \\
1012 \\
1012 \\
1013 \\
1013 \\
1015 \\
1011 \\
1013 \\
1013 \\
1014 \\
1021 \\
1017 \\
1018 \\
1020 \\
1014 \\
1016 \\
1014 \\
1012\end{array}$ & $\begin{array}{l}2 \cdot 7 \\
2 \cdot 5 \\
2 \cdot 5 \\
2 \cdot 3 \\
2 \cdot 5 \\
2 \cdot 2 \\
1 \cdot 5 \\
2 \cdot 2 \\
1 \cdot 7 \\
2 \cdot 0 \\
5 \cdot 0 \\
2 \cdot 2 \\
2 \cdot 5 \\
2 \cdot 5 \\
2 \cdot 6 \\
6 \cdot 0 \\
\\
3 \cdot 0 \\
5 \cdot 0\end{array}$ & $\begin{array}{l}- \\
525 \\
241 \\
262 \\
441 \\
314 \\
269 \\
178 \\
385 \\
437 \\
346 \\
393 \\
175 \\
523 \\
840\end{array}$ & $\begin{array}{l}- \\
- \\
1 \cdot 3 \\
1 \cdot 3 \\
1 \cdot 8 \\
1 \cdot 65 \\
1 \cdot 1 \\
1 \cdot 4 \\
1 \cdot 15 \\
1 \cdot 15 \\
1 \cdot 6 \\
1 \cdot 9 \\
1 \cdot 7 \\
1 \cdot 5 \\
1 \cdot 1 \\
1 \cdot 4 \\
2 \cdot 1 \\
2 \cdot 0\end{array}$ & $\begin{array}{l}- \\
273 \\
136 \\
189 \\
332 \\
230 \\
171 \\
120 \\
221 \\
140 \\
299 \\
267 \\
105 \\
221 \\
196 \\
\\
388 \\
334\end{array}$ & Farinaceous. \\
\hline
\end{tabular}




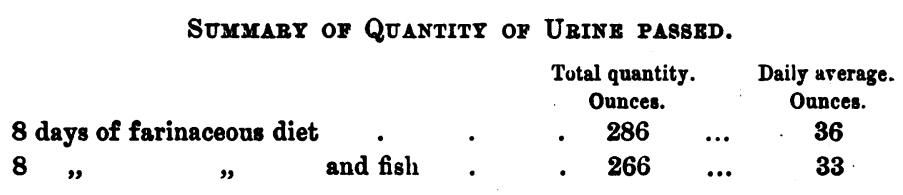

SUMmary of Specipic Gravity.

10 days of farinaceous diet

8 and fish.$\quad \cdot \quad 1012.8$

SUMMARY OF QUANTITY OF ALBUMKN PASEFD.

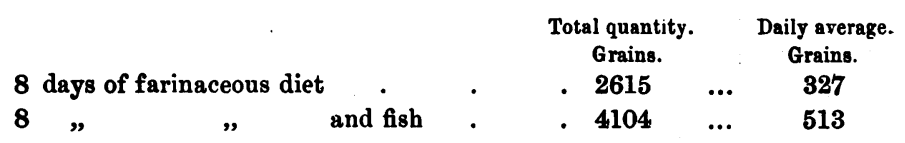

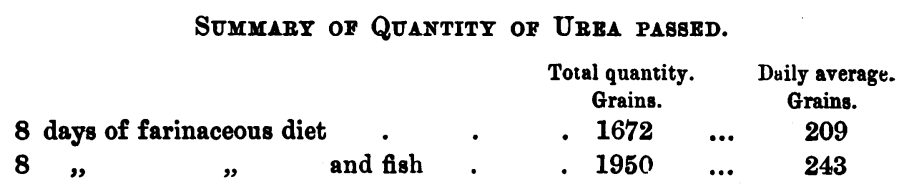

CASE 9. Chronic parenchymatous nephritis.-W. R-, æt. 35, admitted into Guy's Hospital October 23rd, 1891. Clinical clerk, Mr. R. H. Luce.

He has had an abscess under the lower jaw, which has been discharging for the last five years. His legs began to swell about a month ago.

On admission.-There is much œdema of the feet and some of the eyelids. The cardiac dulness extends half an inch outside the nipple. Except for these signs and the albuminuria, nothing else abnormal could be found. Neither the liver nor spleen could be felt. It was possible that the kidneys were to some extent lardaceous. The patient left the hospital on November 30th in the same condition as he was when he came in.

voL. LXXVI. 


\begin{tabular}{|c|c|c|c|c|c|c|c|}
\hline \multirow[b]{2}{*}{ Date. } & \multirow{2}{*}{$\begin{array}{l}\text { No. of } \\
\text { oz. in } \\
24 \text { hrs. }\end{array}$} & \multirow[b]{2}{*}{ Sp. gr. } & \multicolumn{2}{|c|}{ Albugen. } & \multicolumn{2}{|c|}{ URKA. } & \multirow[b]{2}{*}{ Diet. } \\
\hline & & & $\begin{array}{c}\text { Parts } \\
\text { per } \\
1000 .\end{array}$ & $\begin{array}{l}\text { Total } \\
\text { grs. in } \\
24 \text { hrs. }\end{array}$ & $\begin{array}{c}\text { Parts } \\
\text { per } \\
100 .\end{array}$ & $\begin{array}{l}\text { Total } \\
\text { grs. in } \\
24 \mathrm{hrs} .\end{array}$ & \\
\hline $\begin{array}{c}\text { Oct. } \\
24\end{array}$ & 78 & 1018 & - & - & - & - & Faringceons. \\
\hline 26 & 78 & 1011 & $3 \cdot 0$ & $102 \cdot 3$ & 0.95 & 326 & 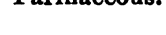 \\
\hline 27 & 72 & 1015 & 2.75 & 86.6 & 1.95 & 617 & \\
\hline 28 & 72 & 1010 & $2 \cdot 5$ & $78 \cdot 7$ & 0.9 & 285 & \\
\hline $2 s$ & 72 & 1010 & $2 \cdot 75$ & $86 \cdot 6$ & 0.95 & 301 & \\
\hline 30 & 54 & 1015 & $5 \cdot 0$ & $114 \cdot 1$ & $1 \cdot 4$ & 332 & Full. \\
\hline 31 & 32 & 1017 & $3 \cdot 0$ & $42 \cdot 0$ & 1.8 & 253 & \\
\hline Nov. & & & & & & & \\
\hline 2 & 48 & 1014 & $5 \cdot 0$ & $105 \cdot 0$ & 1.8 & 380 & \\
\hline $\mathbf{3}$ & 40 & 1014 & $5 \cdot 5$ & 96.2 & $1 \cdot 6$ & 281 & \\
\hline 4 & 40 & 1018 & $7 \cdot 0$ & 122.5 & $1 \cdot 7$ & 299 & \\
\hline 5 & 24 & 1022 & $9 \cdot 0$ & 94.5 & $2 \cdot 3$ & 242 & \\
\hline 6 & 30 & 1027 & $12 \cdot 0$ & 157.5 & $2 \cdot 3$ & 303 & \\
\hline 7 & 20 & 1028 & $12 \cdot 0$ & $105 \cdot 0$ & $2 \cdot 6$ & 228 & \\
\hline 9 & 24 & 1025 & $14 \cdot 0$ & $1477^{\circ} 0$ & $2 \cdot 0$ & 211 & \\
\hline 10 & 32 & 1024 & $14 \cdot 0$ & 196.0 & 2.5 & 320 & \\
\hline 11 & 32 & 1020 & $18 \cdot 0$ & $252 \cdot 0$ & $2 \cdot 1$ & 295 & \\
\hline 12 & 30 & 1025 & $16 \cdot 0$ & $210 \cdot 0$ & $2 \cdot 7$ & 356 & \\
\hline 13 & 16 & 1026 & $28 \cdot 0$ & 196.0 & $3 \cdot 0$ & 217 & \\
\hline 14 & 26 & 1025 & $13 \cdot 5$ & 153.5 & $3 \cdot 0$ & 343 & \\
\hline 16 & 24 & 1022 & $17 \cdot 0$ & 178.5 & $2 \cdot 9$ & 306 & \\
\hline 17 & 48 & 1020 & $13 \cdot 0$ & $273 \cdot 0$ & $2 \cdot 1$ & 443 & \\
\hline 18 & 32 & 1020 & $12 \cdot 0$ & $168 \cdot 0$ & $1 \cdot 9$ & 267 & \\
\hline 19 & 40 & 1022 & $13 \cdot 0$ & $227 \cdot 5$ & $\mathbf{2} \cdot 2$ & 387 & \\
\hline 20 & 44 & 1019 & 8.5 & $163 \cdot 6$ & $1 \cdot 65$ & 319 & \\
\hline 21 & 32 & 1020 & $5 \cdot 0$ & $70 \cdot 0$ & $2 \cdot 05$ & 288 & \\
\hline 23 & 30 & 1022 & $13 \cdot 0$ & $170 \cdot 6$ & $2 \cdot 2$ & 290 & \\
\hline 24 & 44 & 1024 & $12 \cdot 0$ & $231 \cdot 0$ & $2 \cdot 1$ & 369 & \\
\hline 25 & 30 & 1024 & $14: 0$ & $183 \cdot 7$ & $2 \cdot 2$ & 290 & \\
\hline 26 & 24 & 1022 & $14: 0$ & $147^{\circ} 0$ & $2 \cdot 4$ & 253 & \\
\hline 27 & 44 & 1016 & $15 \cdot 0$ & $288 \cdot 7$ & $1 \cdot 45$ & 280 & \\
\hline 28 & 48 & 1018 & $8 \cdot 0$ & 168.0 & $1 \cdot 4$ & 295 & \\
\hline 30 & 60 & 1012 & $12 \cdot 0$ & $\mathbf{3 1 5} 0^{0}$ & $1 \cdot 2$ & 316 & \\
\hline
\end{tabular}

SUMMARY OF QUANTITY OF URINE PASBED.

Total quantity. Daily average. Ounces. Ounces.

$\begin{array}{lllllll}5 & \text { days of farinaceous diet } \quad . \quad & \text {. } & \text { - } & 372 & \ldots & 74\end{array}$

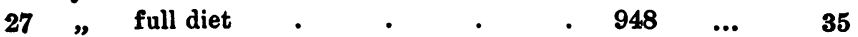

Stgmary of Specific Gravity.

5 days of farinaceous diet $\quad . \quad$. $\quad . \quad . \quad . \quad 1013$ 27 " full diet $\quad . \quad \ldots \quad . \quad . \quad . \quad . \quad . \quad 1020$ 
SUMMLRT OF QUANTITY OF ALBUMEN PASSED.

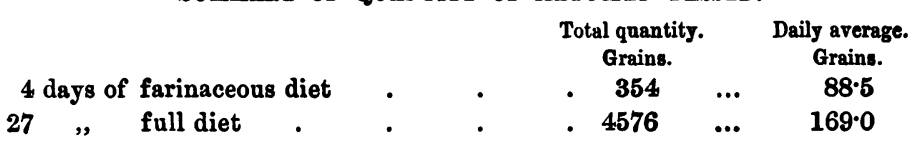

\section{SUMMARY OF QUANTITY OF URHA PAgBED.}

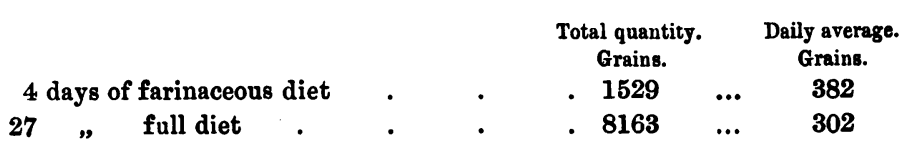

CASE 10. Chronic parenchymatous nephritis.-Michael W-, æt. 49, admitted into Guy's Hospital January 14th, 1891. Clinical clerk, Mr. A. M. Daniel.

He has had syphilis. Three months ago his feet and legs began to swell, and his urine became scanty.

On admission.-The only symptoms were cdema, the alterations in the urine, and some weakness. The liver and spleen could not be felt. He said he always felt much better on full diet than on milk or farinaceous. He left the hospital on February 13th. The cdema was less than on admission.

\begin{tabular}{|c|c|c|c|c|c|c|c|}
\hline \multirow[b]{2}{*}{ Date. } & \multirow{2}{*}{$\begin{array}{l}\text { No. of } \\
\text { oz. in } \\
24 \mathrm{hrs} \text {. }\end{array}$} & \multirow[b]{2}{*}{ Sp. gr. } & \multicolumn{2}{|c|}{ ALbUMEx. } & \multicolumn{2}{|c|}{ UREA. } & \multirow[b]{2}{*}{ Diet. } \\
\hline & & & $\begin{array}{c}\text { Parts } \\
\text { per } \\
1000 .\end{array}$ & $\begin{array}{l}\text { Total } \\
\text { grs. in } \\
24 \mathrm{hrs} .\end{array}$ & $\begin{array}{l}\text { Parts } \\
\text { per } \\
100 .\end{array}$ & $\begin{array}{l}\text { Total } \\
\text { grs. in } \\
24 \text { hrs. }\end{array}$ & \\
\hline Jan. & & & & & & & \\
\hline 15 & - & 1012 & 3·25 & - & $1 \cdot 1$ & $=$ & Farinaceous. \\
\hline 16 & 58 & 1014 & $4: 0$ & 102 & $1 \cdot 0$ & 255 & \\
\hline 17 & 86 & 1014 & $1 \cdot 0$ & 37 & $\cdot 75$ & 283 & Foll diet \\
\hline 18 & $\overline{-1}$ & $\overline{0 x}$ & $\overline{10}$ & $\overline{99}$ & $\overline{1 \cdot 1}$ & $\overline{348}$ & Full diet. \\
\hline 19 & $\begin{array}{l}72 \\
68\end{array}$ & $\begin{array}{l}1015 \\
1016\end{array}$ & $\begin{array}{l}7.0 \\
9.0\end{array}$ & $\begin{array}{l}221 \\
268\end{array}$ & $\begin{array}{l}1 \cdot 1 \\
1 \cdot 1\end{array}$ & 309 & \\
\hline 21 & 72 & 1018 & $9 \cdot 0$ & 285 & $1 \cdot 4$ & 444 & \\
\hline 22 & 48 & 1017 & $8 \cdot 0$ & 168 & $1 \cdot 5$ & 422 & \\
\hline 23 & 60 & 1020 & $10 \cdot 0$ & 284 & $1 \cdot 6$ & 422 & Milk only, 6 pints. \\
\hline 24 & 60 & 1015 & $7 \cdot 0$ & 184 & $1 \cdot 4$ & 367 & \\
\hline 26 & 80 & 1011 & $5 \cdot 0$ & 186 & $1 \cdot 2$ & 422 & \\
\hline 27 & 82 & 1011 & $4: 0$ & 124 & $1 \cdot 3$ & 469 & \\
\hline 28 & 72 & 1011 & $5 \cdot 0$ & 158 & $1 \cdot 3$ & 411 & \\
\hline 29 & 62 & 1015 & $6 \cdot 0$ & 163 & $1 \cdot 6$ & 436 & \\
\hline 30 & 64 & 一 & $6 \cdot 0$ & 168 & - & - & Full diet. \\
\hline
\end{tabular}




\begin{tabular}{|c|c|c|c|c|c|c|c|}
\hline \multirow[b]{2}{*}{ Date. } & \multirow{2}{*}{$\begin{array}{l}\text { No. of } \\
\text { oz. in } \\
24 \text { hrs. }\end{array}$} & \multirow[b]{2}{*}{$\begin{array}{l}\text { Sp.gr. } \\
.\end{array}$} & \multicolumn{2}{|c|}{ Albuman. } & \multicolumn{2}{|c|}{ UREA. } & \multirow[b]{2}{*}{ Diet. } \\
\hline & & & $\begin{array}{c}\text { Parts } \\
\text { per } \\
1000 .\end{array}$ & $\begin{array}{l}\text { Total } \\
\text { grs. in } \\
24 \text { hrs. }\end{array}$ & $\begin{array}{c}\text { Parts } \\
\text { per } \\
100 .\end{array}$ & $\begin{array}{l}\text { Total } \\
\text { grss in in } \\
24 \mathrm{hrs}\end{array}$ & \\
\hline $\begin{array}{c}\text { Feb. } \\
4 \\
6 \\
7 \\
9 \\
10 \\
11 \\
12 \\
13\end{array}$ & $\begin{array}{l}42 \\
40 \\
70 \\
40 \\
60 \\
44 \\
40 \\
36\end{array}$ & $\begin{array}{l}1015 \\
1018 \\
1015 \\
1021 \\
1020 \\
1020 \\
1017 \\
1018\end{array}$ & $\begin{array}{r}7 \cdot 0 \\
6.0 \\
6.0 \\
9 \cdot 0 \\
9 \cdot 0 \\
10 \cdot 0 \\
7 \cdot 0 \\
8.0\end{array}$ & $\begin{array}{l}135 \\
105 \\
184 \\
158 \\
237 \\
171 \\
153 \\
126\end{array}$ & $\begin{array}{l}1 \cdot 5 \\
1 \cdot 6 \\
1 \cdot 4 \\
1 \cdot 8 \\
1 \cdot 7 \\
1 \cdot 8 \\
1 \cdot 8 \\
1 \cdot 8\end{array}$ & $\begin{array}{l}290 \\
281 \\
431 \\
316 \\
448 \\
348 \\
316 \\
284\end{array}$ & Full diet. \\
\hline
\end{tabular}

SUMMARY OF QUANTITY OF URINE PASSED.

Total quantity. Daily average.

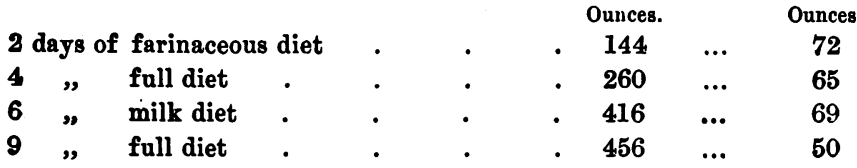

SUmmary of Specific Gravity.

\begin{tabular}{|c|c|c|c|c|c|c|c|c|}
\hline \multirow{2}{*}{\multicolumn{4}{|c|}{3 days of farinaceous diet }} & & & & & \multirow{2}{*}{$\begin{array}{c}\text { Daily avera } \\
\text { - } 1013 \cdot 3\end{array}$} \\
\hline & & & & • & - & - & . & \\
\hline 4 & ", & full diet & . & - & . & - & . & $1018 \cdot 5$ \\
\hline 6 & " & milk diet & . & . & • & • & • & $1013 \cdot 8$ \\
\hline 8 & " & full diet & - & - & . & - & . & $1018^{\circ} 0$ \\
\hline
\end{tabular}

SUMMARY OF QUANTITY OF ALBUMRN PASSED.

Total quantity. Daily average. Grains. Grains.

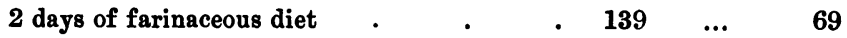

4 " full diet $\quad . \quad$. $\quad$. $\quad \begin{array}{lllll} & \text {. } & 942 & \ldots & 271\end{array}$

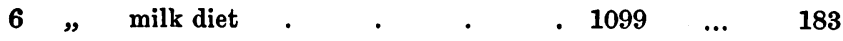

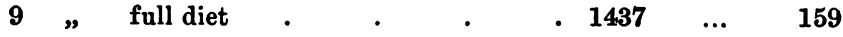

SUMmary OF QUANTity OF UREa Pasged.

Total quantity. Daily average.

\begin{tabular}{|c|c|c|c|c|c|c|c|c|}
\hline & ays of farinaceou & diet & & - & & $\begin{array}{r}\text { Grains. } \\
5338\end{array}$ & ... & $\begin{array}{r}\text { Grains } \\
269\end{array}$ \\
\hline & full diet & . & & $\cdot$ & & 1523 & $\ldots$ & 38 \\
\hline & milk diet & . & 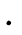 & • & & 2527 & $\ldots$ & 4 \\
\hline & full diet & . & . & . & & 2714 & .. & \\
\hline
\end{tabular}

(For report of the discussion on this paper, see 'Proceedings,' New Series, vol. v, p. 103.) 